\title{
أدب التخاطب في السنة النبوية الشريفة
}

د. هسمود بن همهمد القهطاني

الأستاذ المساعد في الكتاب و المنة- قسم الثريعة والدراسات الإسلامية- كلية الآداب والعلوم الإنسانية- جامعة الملك عبد

العزيز بجدة- الملكة العربية السعودية

malqahtany@kau.edu.sa

مستخلص:

الحمد لله رب العالمين، وصلى الله وسلم على نبينا محمد وآله وصحبه أجمعين، أما بعد، أهمية البحث: كان النبي

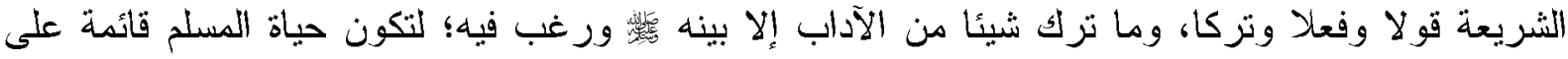

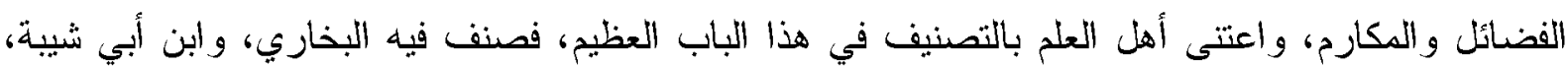
و البيهقي في آخرين.

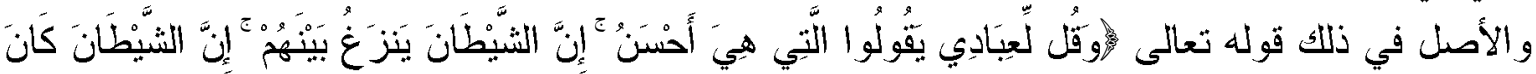

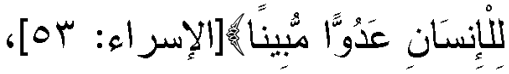

ويعتمد البحث على الطريقة الموضو عية والاستقر ائية من خلال جمع الأحاديث النبوية الثريفة التي تتحدّث

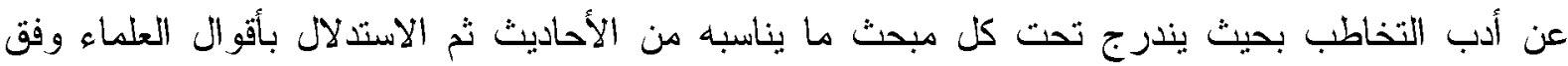
المنهج العلمي. تتكون خطة البحث من مقدمة وخاتمة وفهرس المصادر و المر اجع وبينهما عثرة مباحث.

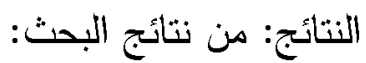

ا- الإخلاص لله تعالّى من أجل الآداب التي ينبغي للمتخاطبين التحلي بها، فهو ميزان الأعمال و عليه تدور رحى القبول.

ץ- الجدال والمراء والخصومة من آفات الحوار والتخاطب بين الناس، ومتى سرت هذه الأدواء إلى الخطاب كان ما بفسده أكثر مما يصلحه. التوصيات:

يوصي الباحث بضرورة إحباء أدب السنة النبوية الشريفة في التخاطب في بين أفراد المجتمع من خلال المحاضر ات و الدورات وخطب الجمعة و الفيديو هات القصيرة ووسائل التو اصل الاجنماعي.

$$
\text { فهرس المصادر و المر اجع. }
$$

Summary:

Praise be to God, Lord of the worlds, and peace and blessings of God be upon our

Prophet Muhammad and his family and companions as a whole. As for yet, these are the most important The research included conversation literature in the noble prophetic Sunnah And it depends on the inductive scientific method in tracing the hadiths of the Holy Prophet, so that what suits him from the hadiths of the Prophet are included under each topic, and then deducing the sayings of scholars according to the scientific method. 
results which I have reached after God made it easy to complete this research, and they are: 1 - Maintaining sincerity in all deeds to God Almighty for the sake of the morals that the interlocutors should adhere to, for it verily is an extremely fundamental criterion upon which acceptance can be sought. 2 - Disputatious argumentation and rivalry are awful blights on the well-being of constructive dialogue and communication between people; once proven evident in any discourse one may expect animosity rather than harmony. The researcher recommends the necessity to revive the literature :Recommendations of the noble Prophet's Sunnah in communicating among members of society through Index of sources and .lectures, courses, Friday sermons, short videos and social media .references

أدب التخاطب في السنة الثبوية الثشريفة

المقدمة:

الحمد الله رب العالمين، وصلى الله وسلم على نبينا محمد وآله وصحبه أجمعين، أما بعد، فإن الآدابَ

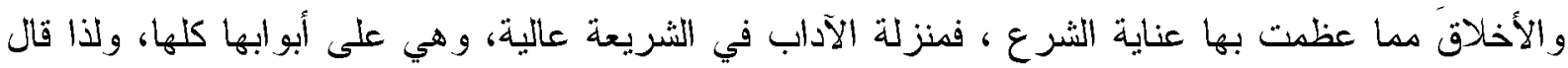

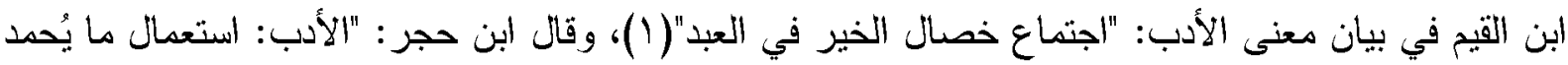

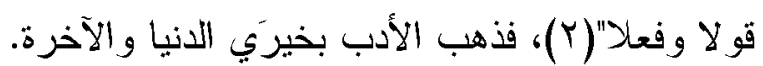

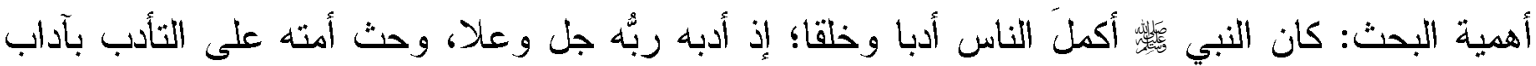

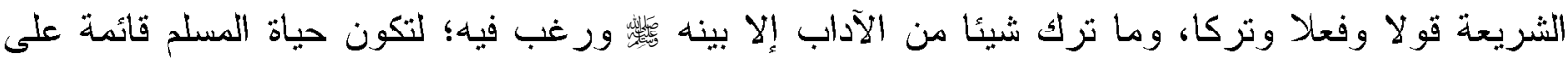

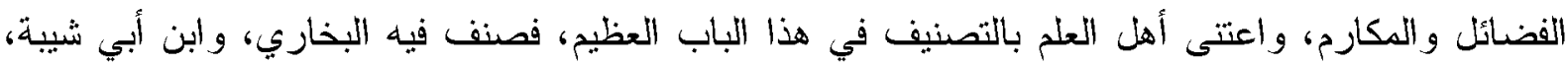
و البيهقي في آخرين. و الناظر اليومَ في أحوال الناس يجد تقصيرا ظاهرا في هذا الباب عند الخاصة والعامة، ومن الآداب العظيمة التي حصل فيها الغلط والتقبير: أدب التخاطب؛ وأعني بذلك ما يقع بين الناس في أحاديثه و مجالسهح ومنتدياتهر وما يتصل بذلك، ويدخل في ذلك ما يقع في مجالس العلم و البحث و المناظرة وما إليها،

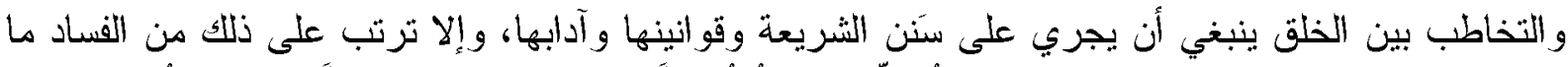

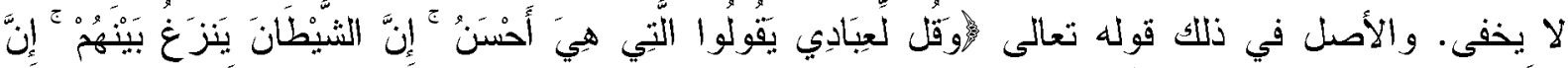

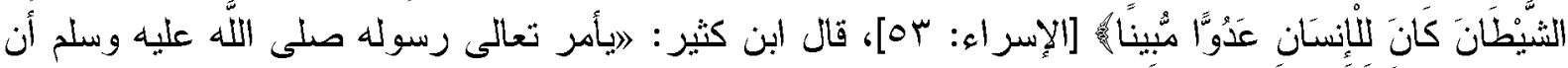

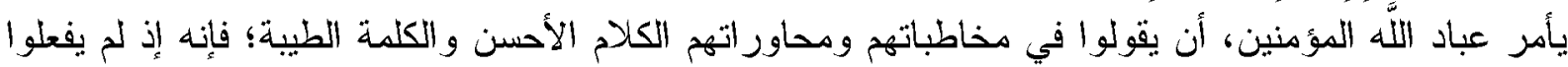

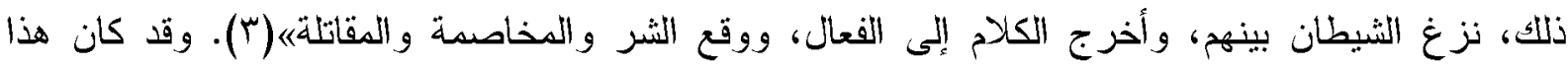
الباعث لي على كتابة هذا البحث الذي عنونته "أدب التخاطب في السنة النبوية"، و اقتصرت فيه وفيه على مهمات الآداب، وما يكثر فيه الغلط، إذ البسط و التفصيل بطول، ولاع يتسع له المقام .

$$
\begin{aligned}
& \text { (1) مدارج النسالكين (r/.ء؛ (1). }
\end{aligned}
$$

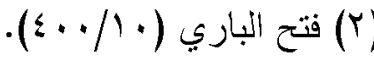

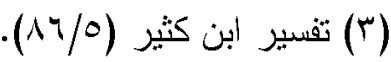


منهج البحث: يعتمد البحث على الطريقة الموضو عية والاستثر ائية من خلال جمع الأحاديث النبوية الثريفة التي تتحدّث عن أدب التخاطب بحيث يندرج تحت كل مبحث ما يناسبه من الأحاديث ثم الاستدلال بأقوال

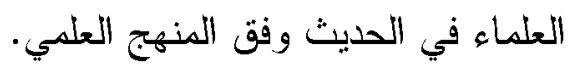
خطة البحث: يتكون البحث من مقدمة وخاتمة وفهرس الدصادر والمراجع وبينهما عشرة مباحث على

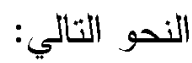

المبحث الأول: الإخلاص لله تعالتى في الخطاب. المبحث الثاني: العطم بمادة الخطاب. المبحث الثالث: الصدث في الخطاب. المباد بادة الخطاب.

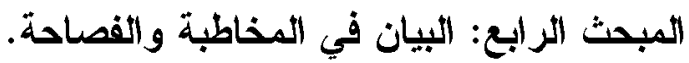

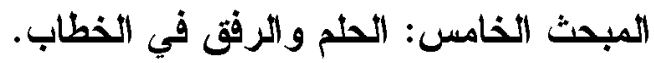

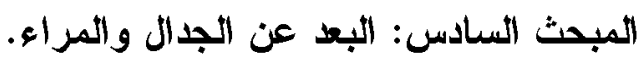
المبحث السابع: الإعراض عن اللغنو وما لا فائدة فيه.

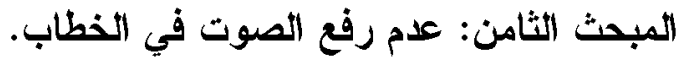
المبحث التاسع: حسن الإصغاء للمتكلم.

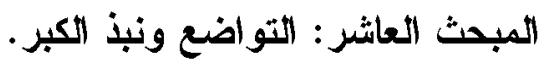
الخاتمة وفيها أهم النتائج و التوصيات التواتير

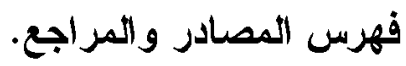
و وآخر دعوانا أن الحمد لله رب العالمين

أدب التخاطب في السنة النبوية الثريفة المبحث الأول: الإخلاص لله تعالى في الخطاب: الإخلاص ميزان الأعمال، وعليه تذور رَحى القبول، وحقيقته: أن يبتغي العبد بعمله وجه الله، لا بعمل رياء

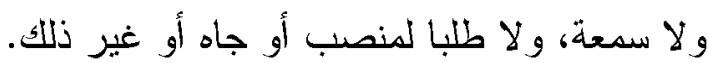

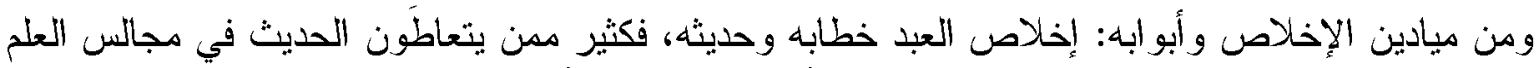

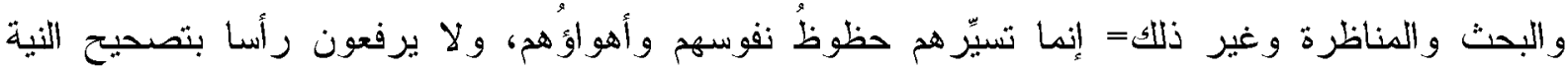

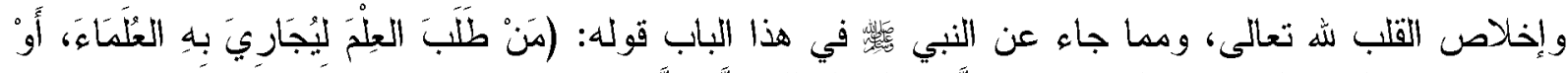

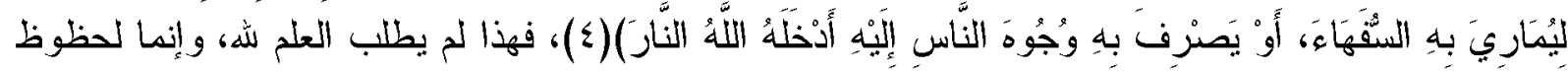

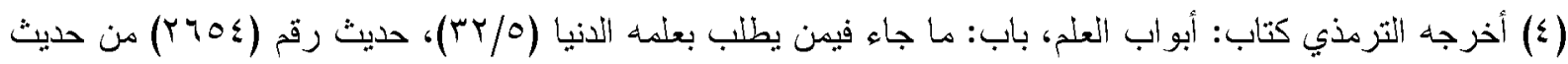

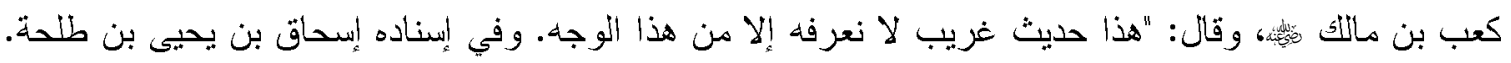

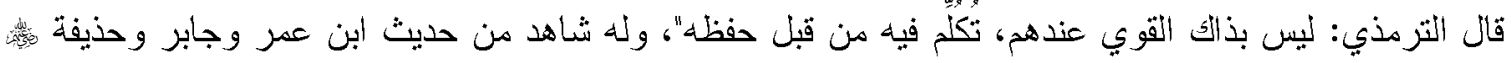

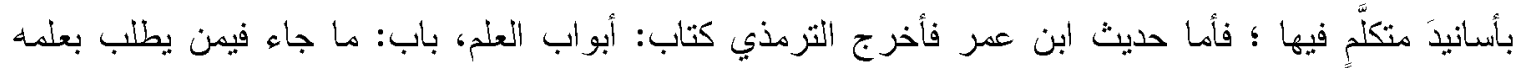

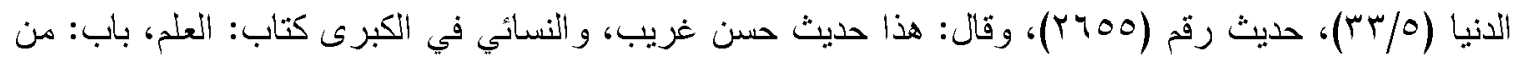

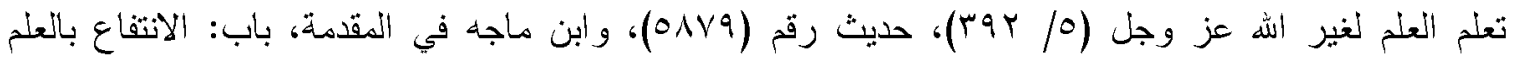


النفس، والاستعلاء على الخلق، وصرف الوجوه إليه، وطلب الحَظوة والمال و الجاه و المفاخرة وغير ذلك مما يقدح في أصل عمله، فكان جزاؤه النار و العياذ بالله.

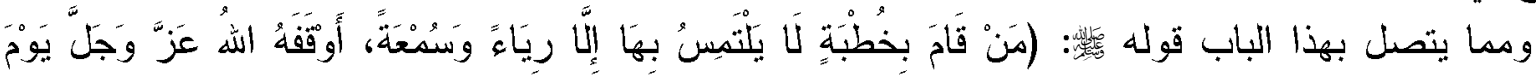

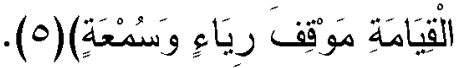

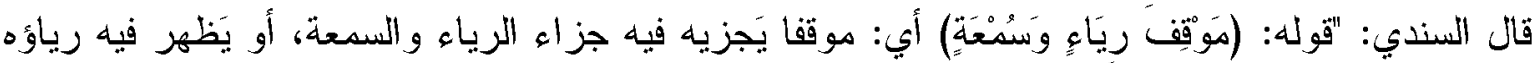

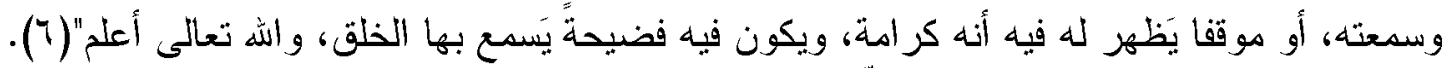

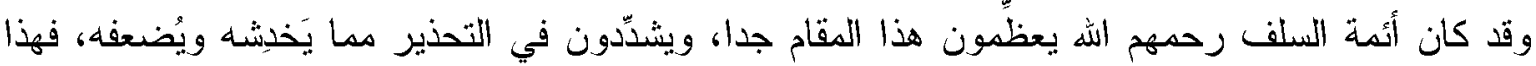

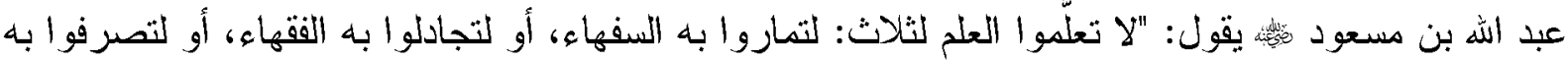

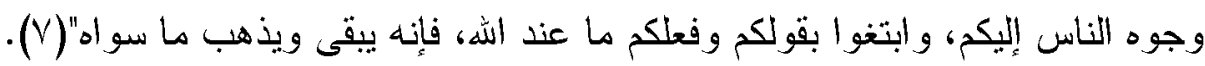

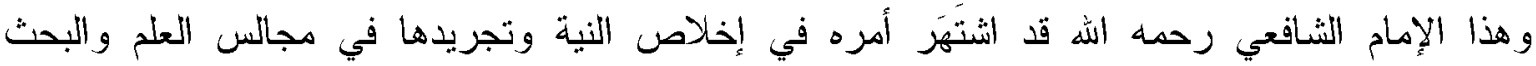

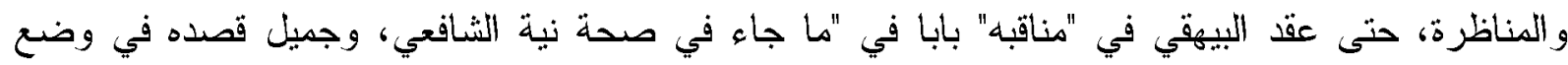

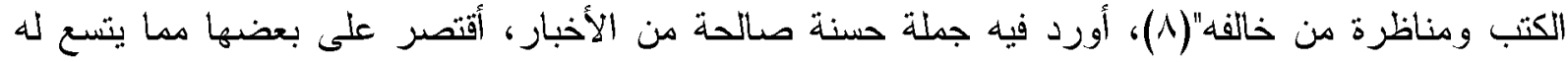
البحث هنا. عن الربيع بن سليمان الـــر ادي قال: سمعت الثافعي يقول: "ما ناظرت أحدا قط على الغلبة، وبودي أن جميع الخلق تعلمو ا هذا الكتاب -يعني كتبه-، ولان يُنسب إلبيّ شيء منهة. وقال رحمه الله: "ما ناظرت أحدا قط إلا على النصيحة".

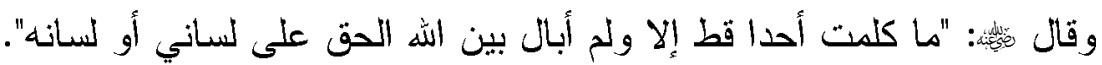
وبمثل هذا ارتفع الإمام الشافعي، وخضع الناس لعلمه، وبلغ ما بلغ، فلم يكن يبغي الغلبة و الثهرة و الظهور على خصومه، بل كان ينشد الحق ولو على لسانهم، مدا يذل على تجرده، ولهذا كان كثير مدن يناظرهم

و العمل به (1/19)، حديث رقم (YOr). وأما حديث جابر ؛ فأخرجه ابن ماجه في المقدمة، باب: الانتقاع بالعلم

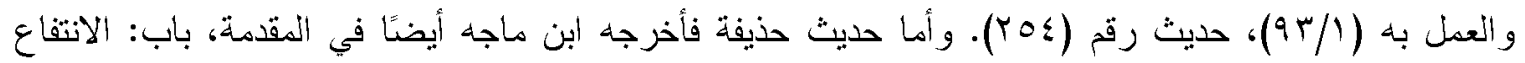

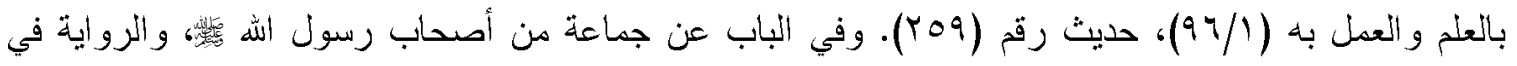

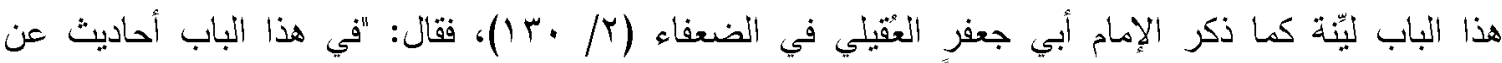

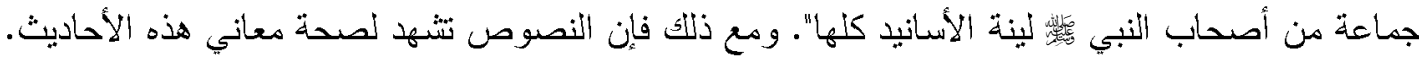

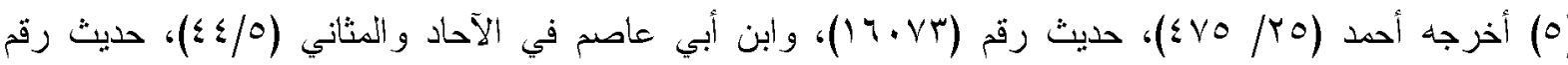
(YONY)

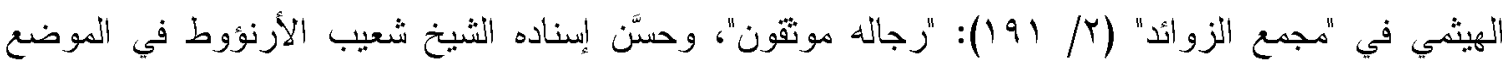
المشار إليه من المسند.

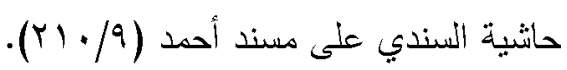

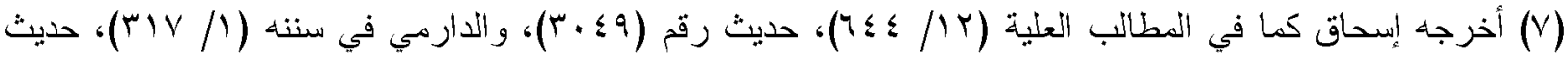

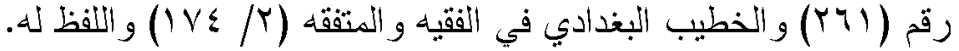

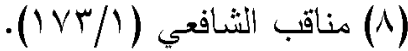




\section{الشافعي ويجادلونه يرجعون عن أقو الهم ومذاهبهج(9). المبحث الثاني: العطم بمادة الخطاب:} أعجبتني كلمة -كنت قد قر أتها قديما- للأستاذ محمد الر اشد يقول فيها: "العلم بالتعلم، ولا بد من أخذ النفس

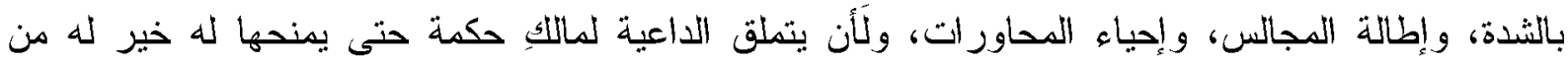

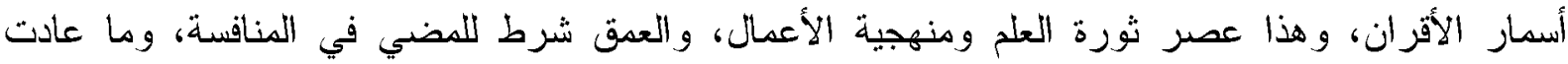

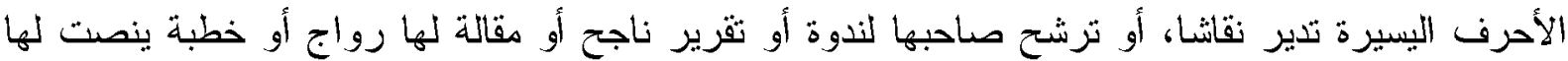

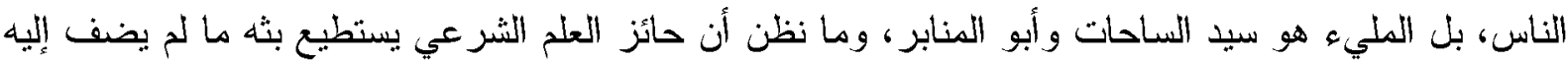

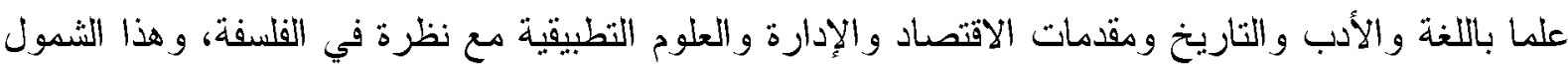
هو مظنة تأثيره في أوساط المثقفين، وبدونه يتلعثم أو يضطرب واب عرضده" (• (1).

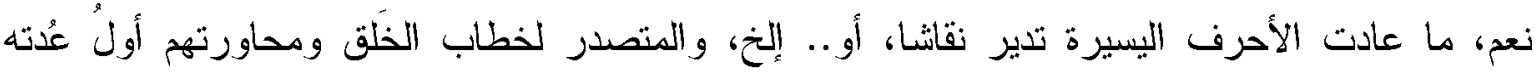

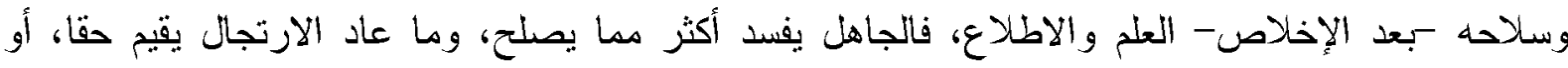

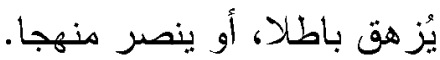

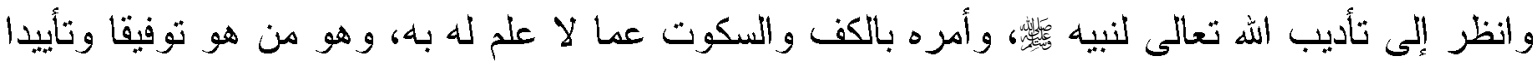
من رباه.

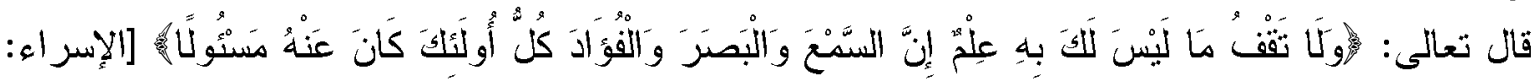

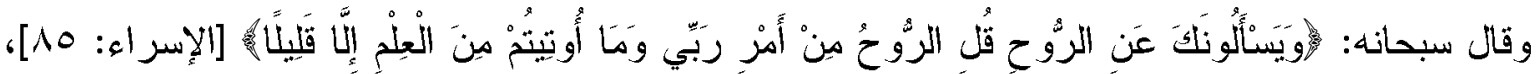
و الآيات في الباب كثيرة، و المقصود هنا التمثيل.

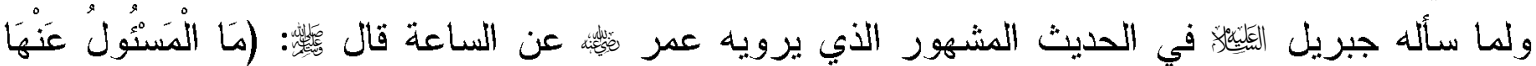

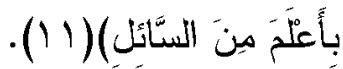

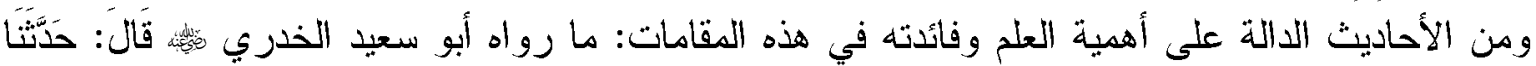

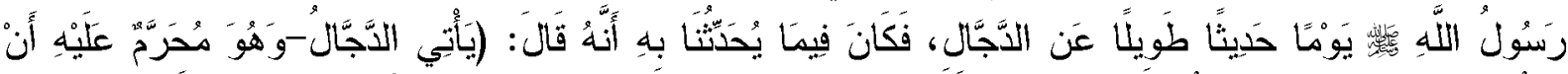

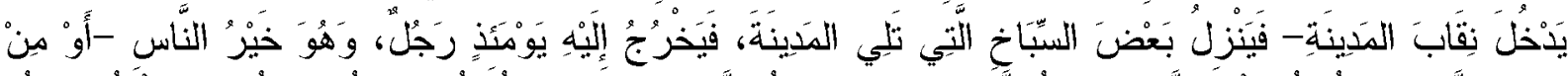

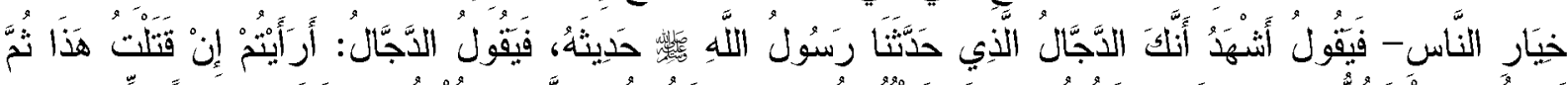

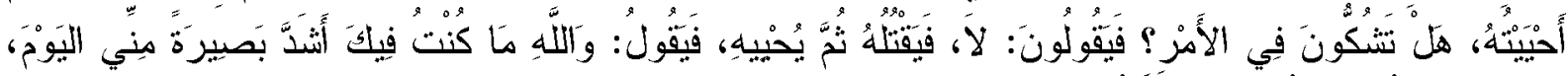

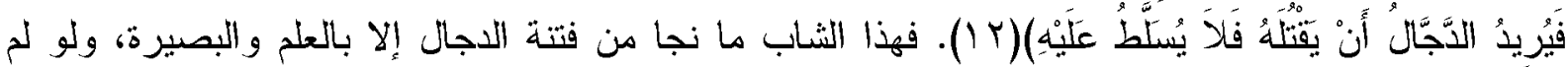

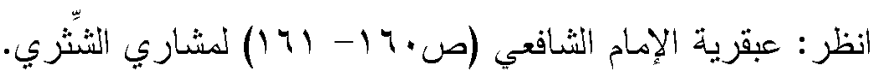

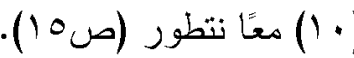

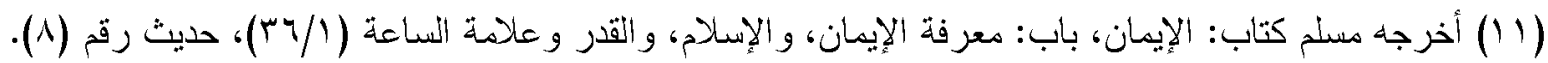

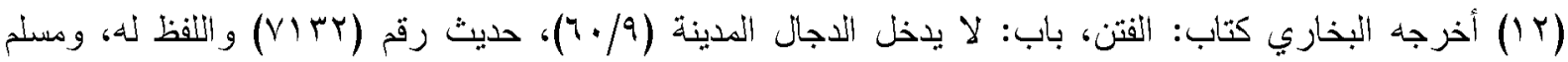

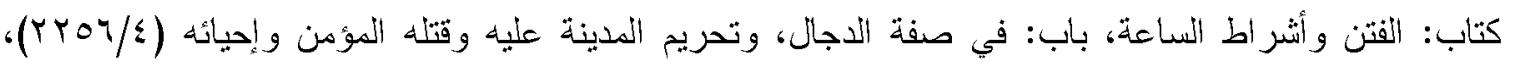

$$
\text { حديث رقم (r (r r). }
$$




\section{يكن بصير ا بأمر الاجال لضل مع من ضلو ا، وفُتن مع من فنتو ا.}

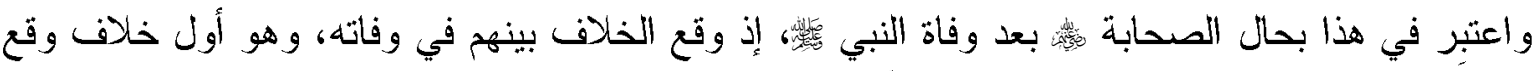

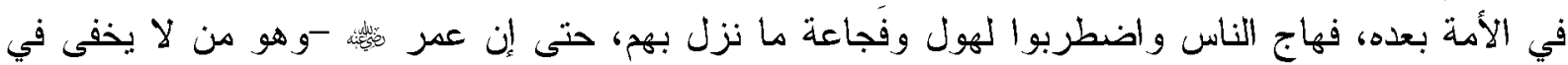

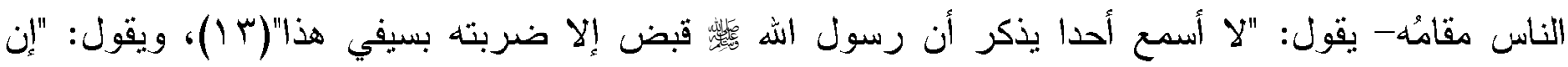

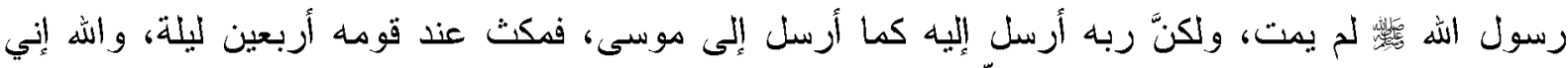

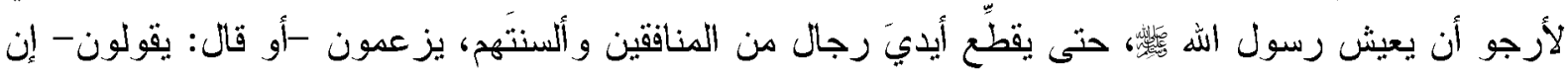

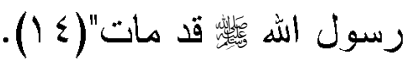

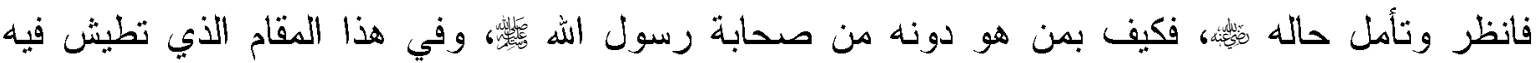

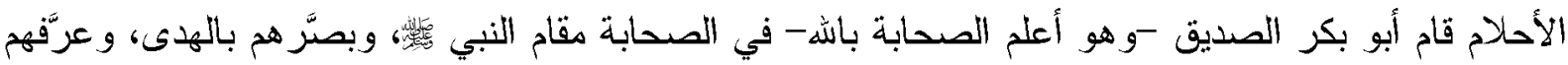
الحق الذي عليه.

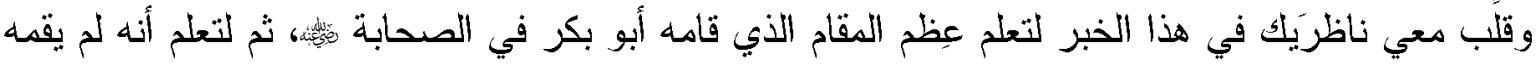
إلا بما معه من العلد.

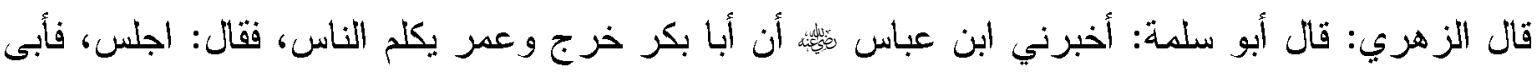

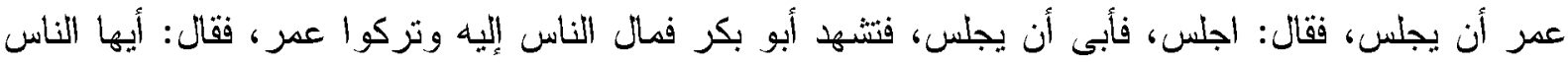

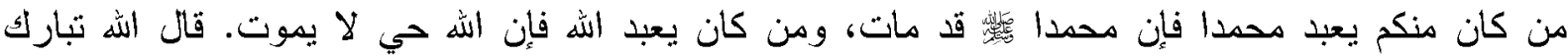

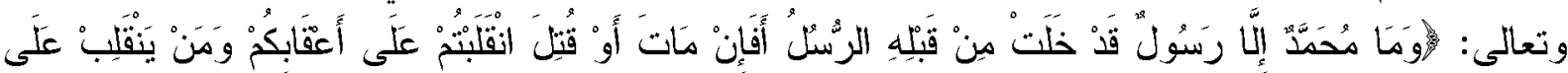

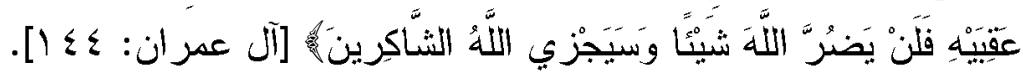

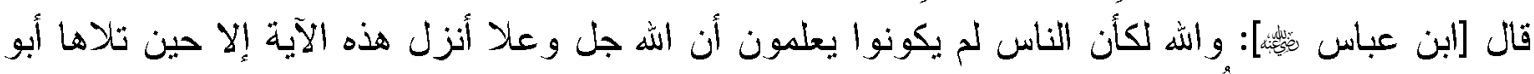

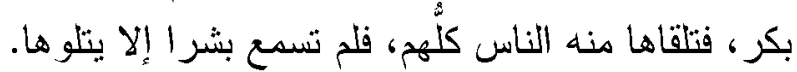

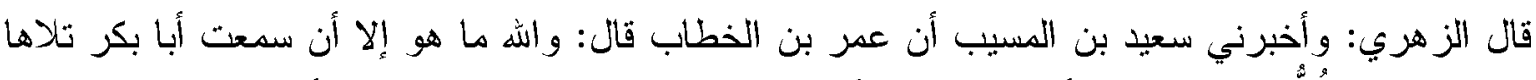

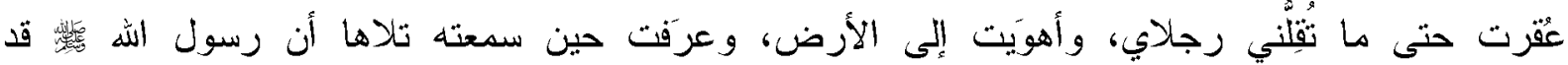
مات (10) مات (10)

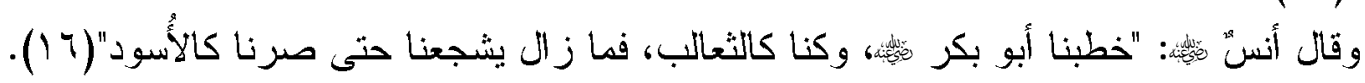
(r (ا) أخرجه الترمذي في "الثمائل المحمدية"، باب: ما جاء في وفاة النبي صلى الله عليه وسلم (صبسب)، حديث رقم

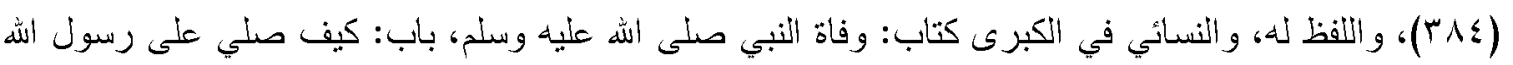

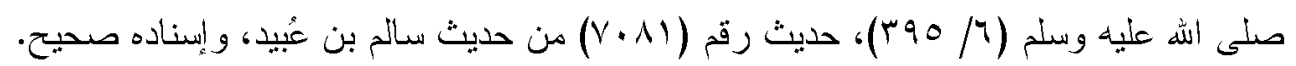

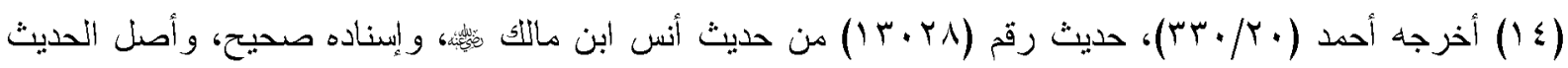
متفق عليه. (10) أخرجه البخاري تعليقا، كتاب: الجنائز ، باب: الاخول على المبيت بعد الموت إذا أدرج في أكفانه (T/ / (V)، عقيب

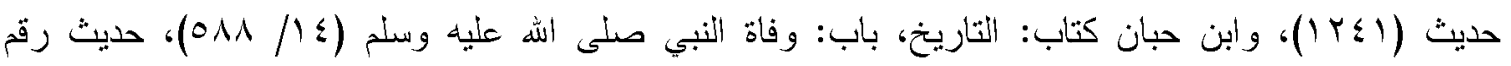

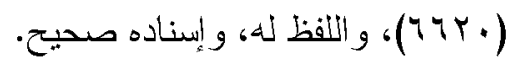

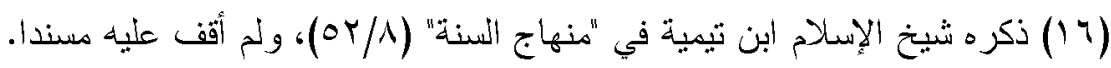




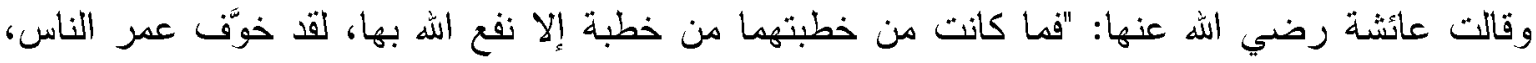

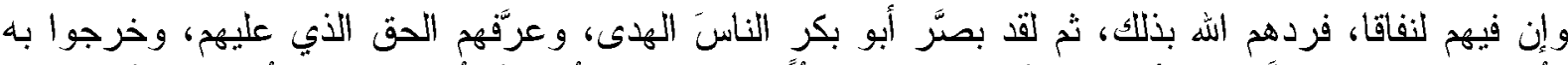

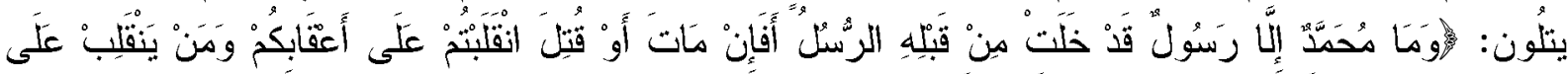

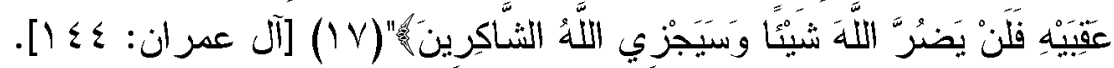

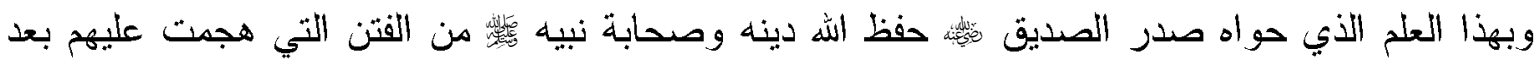

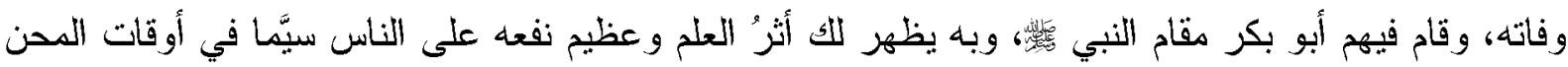
و الثدائد.

المبحث الثالث: الصدق في الخطاب: "صدق اللهجة: عنوان الوقار ، وشرف النفس، ونقاء السريرة، وسمو الهمة، ورُجحان العقل، ورسول المودة

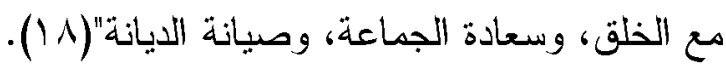

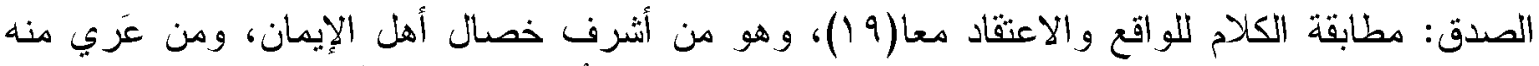

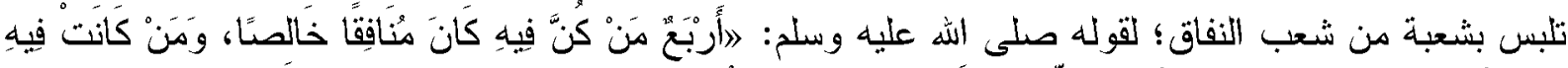

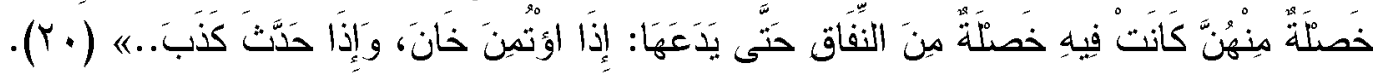

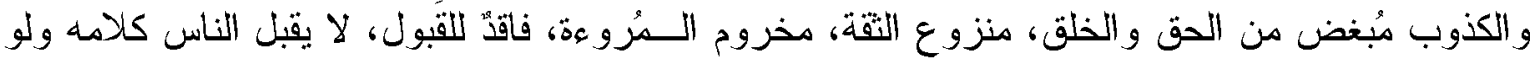

صدق.

وصدق المرء في حديثه ومجالسه من أعظم أسباب القبول والتوفيق، فالصادق في خطابه نور، ولكلامها

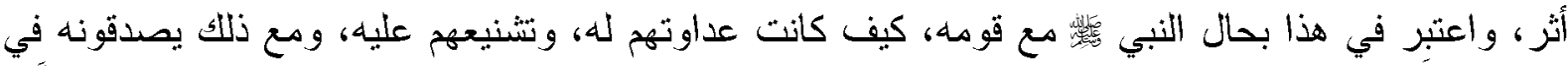

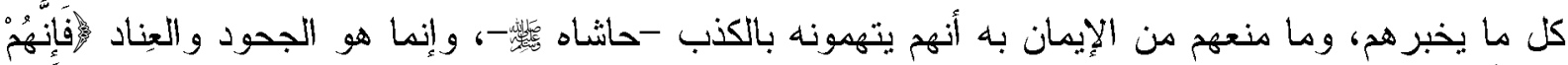

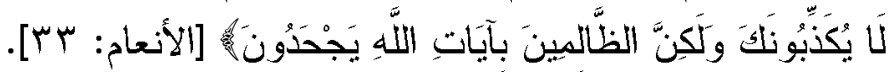

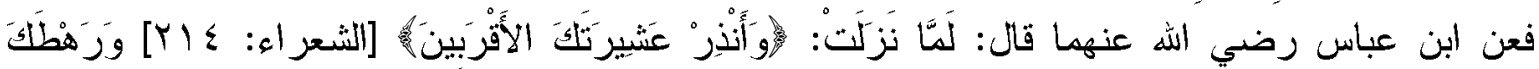

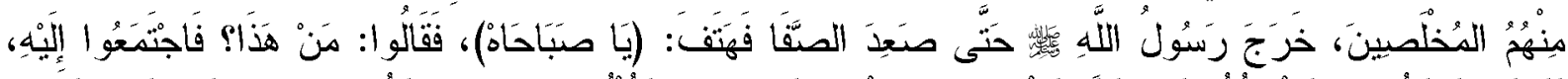

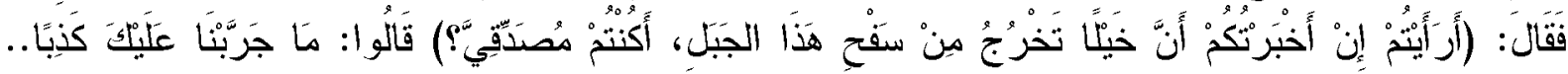

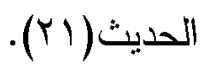

(V) أخرجه البخاري تعليقًا كتاب: أصداب النبي صلى الله عليه وسلم، باب: قول النبي صلى الله عليه وسلم: الو الو

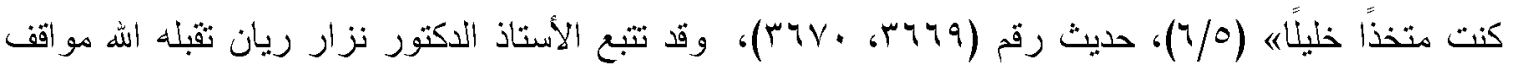

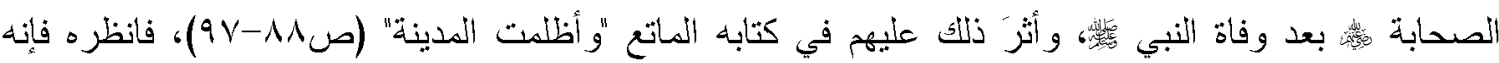

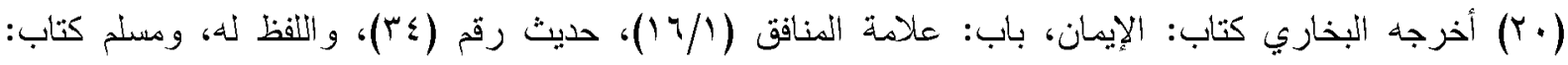

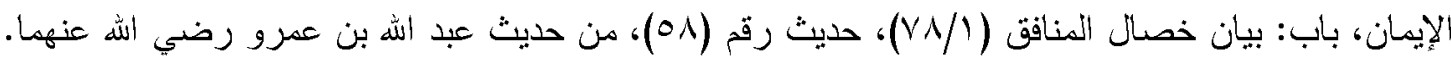

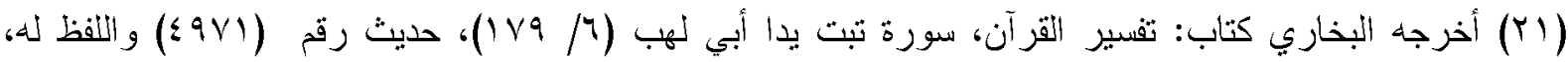


فانظر كيف صدقوه في هذا الأمر العظيم الجلا، لأنهم لم يجربوا عليه الكذب، فالصدق معدِنه وشعاره

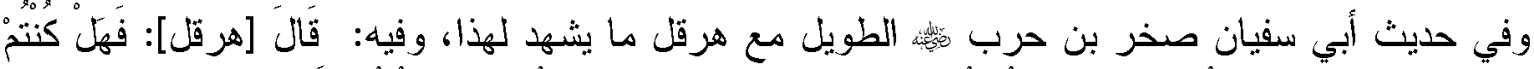

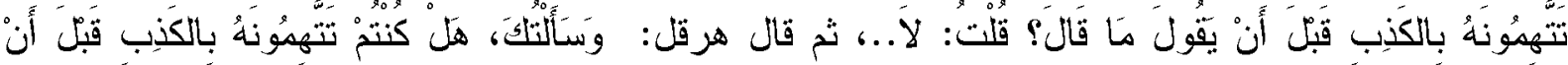

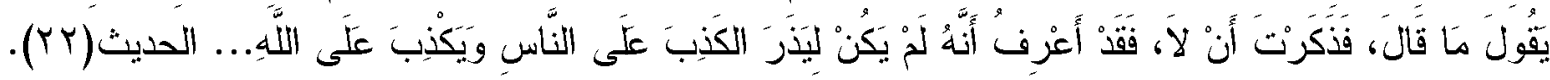

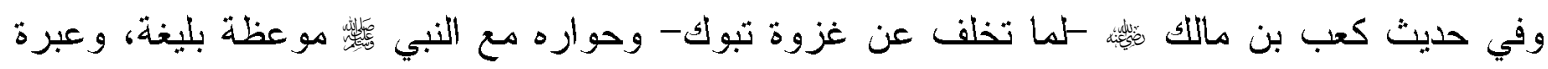

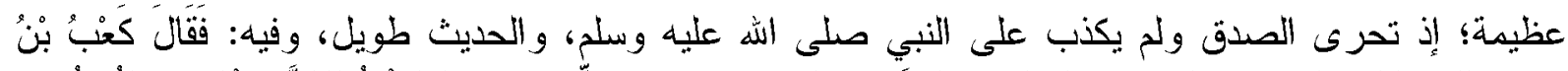

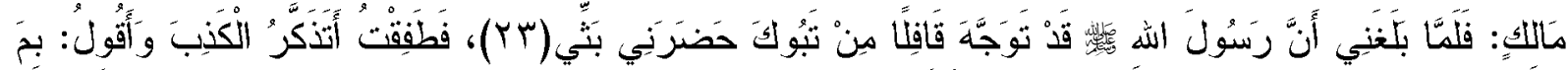

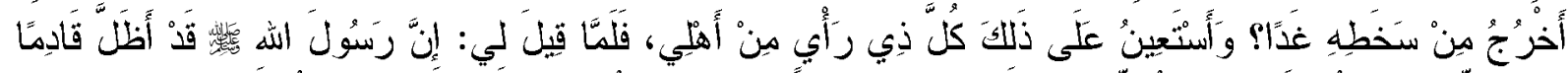

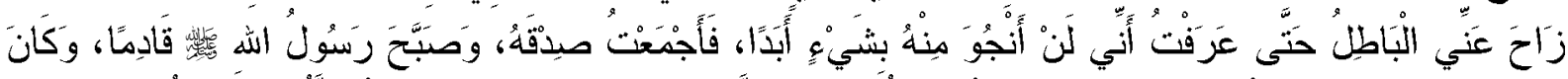

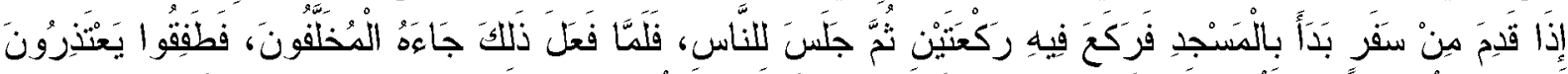

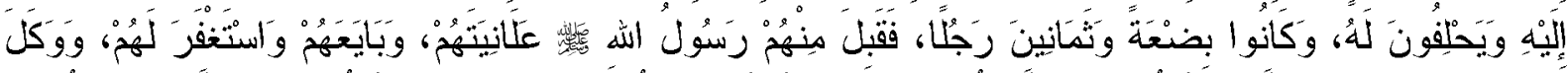

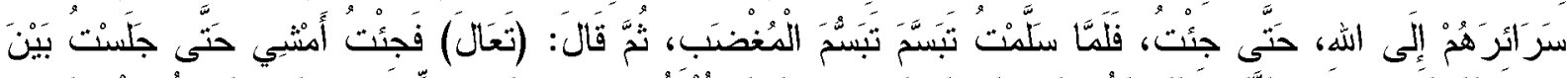

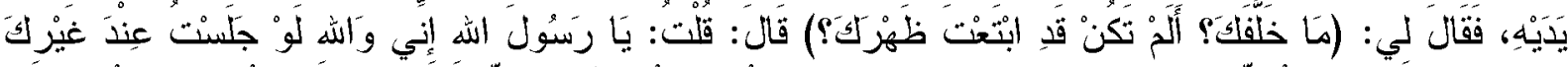

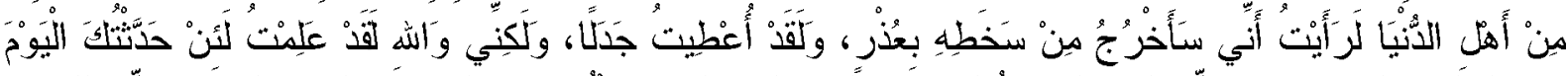

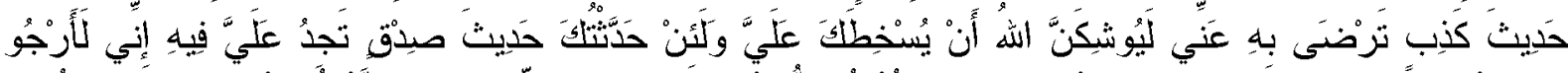

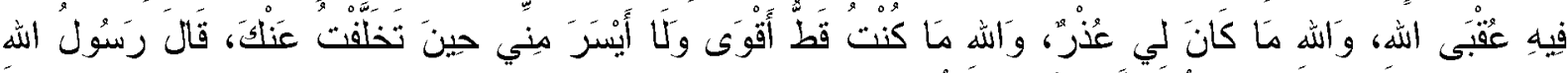

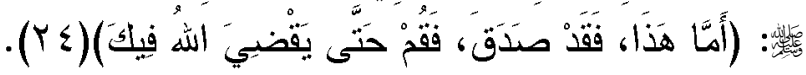

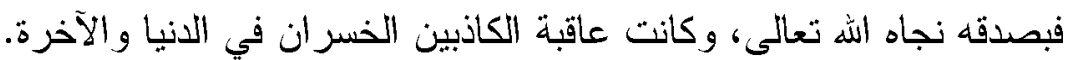

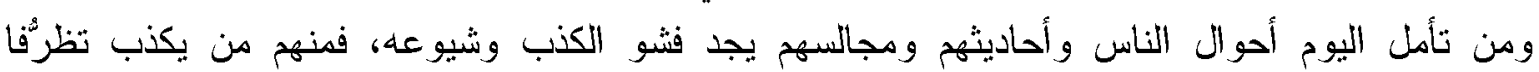

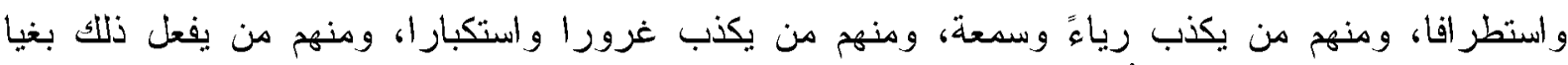

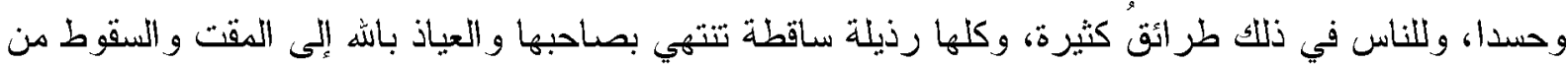

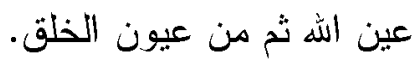

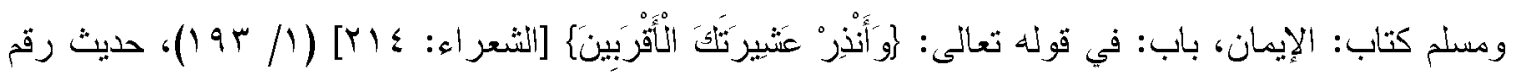

(Y) أخرجه البذاري كتاب: بدء الوحي، باب: كيف كان بدء الوحي إنى رسول الله صلى الله عليه وسلم (I/I)؛

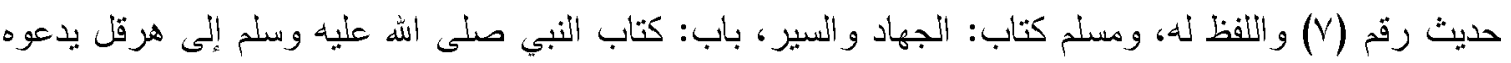

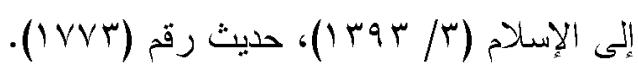

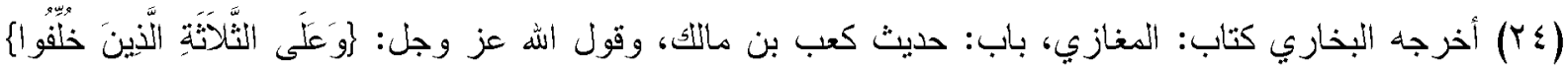

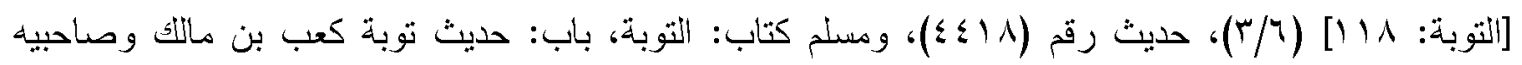

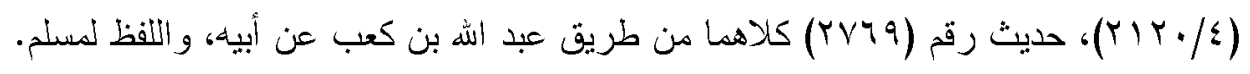




\section{المبحث الرابع:البيان في المخاطبة و الفصاحة:}

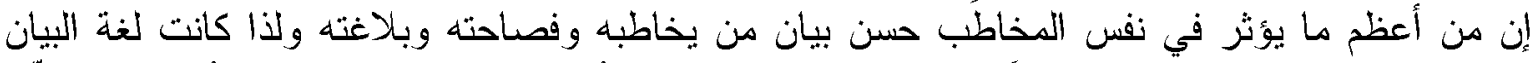

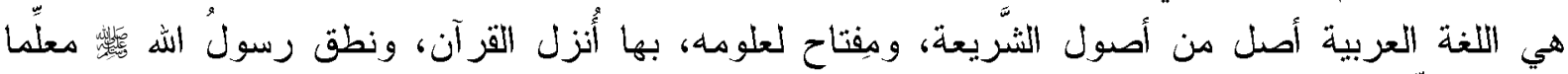
ومبيّنا ومبلًّا.

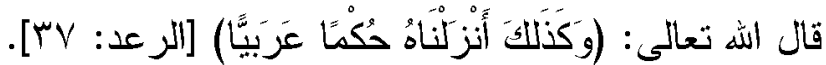

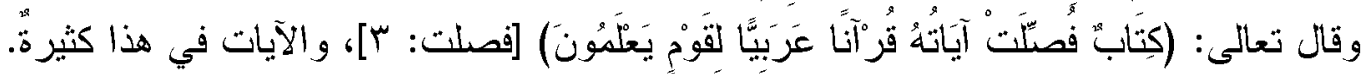

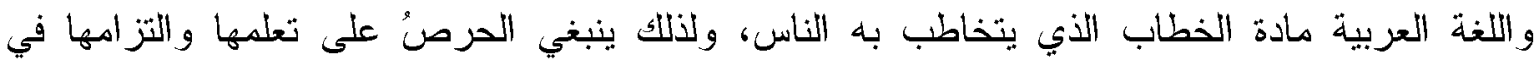
مجالس العلم والحديث و الحوار و المناظرة وغير ذللك مما يتصل بحياة الناس.

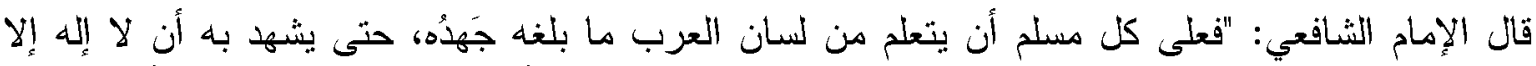

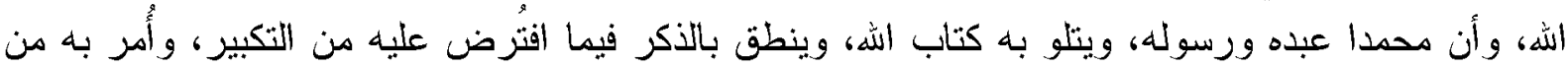

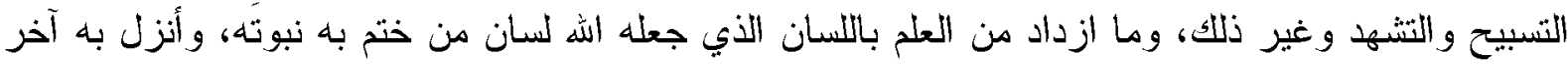

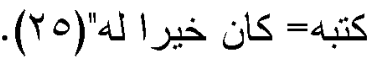

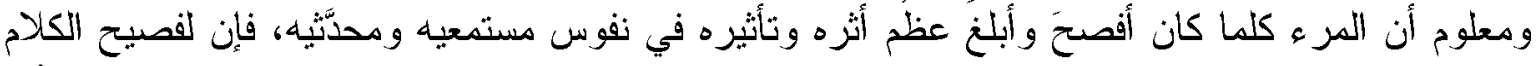

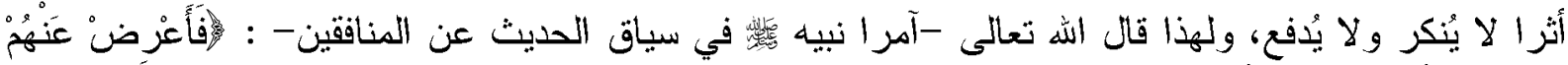

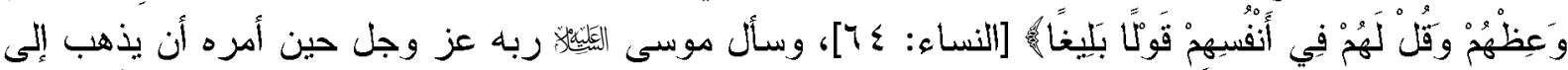

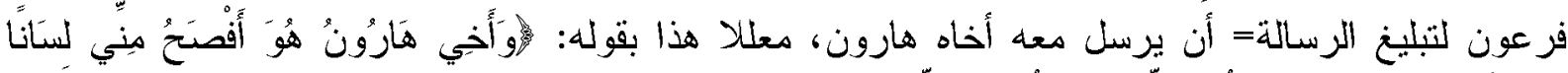

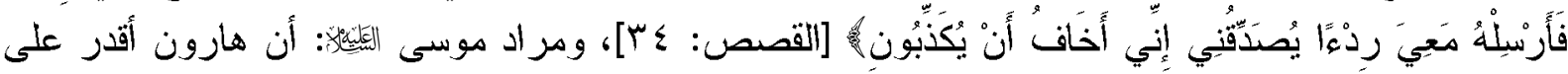

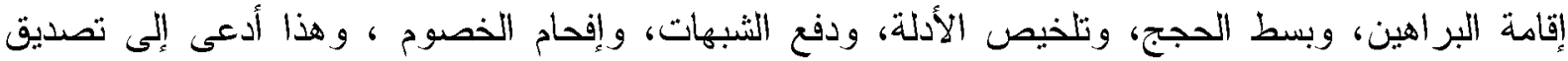

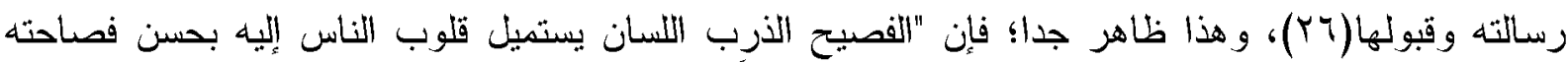

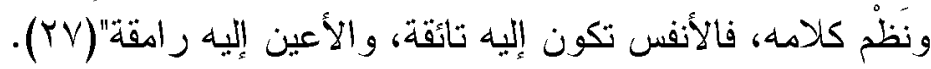

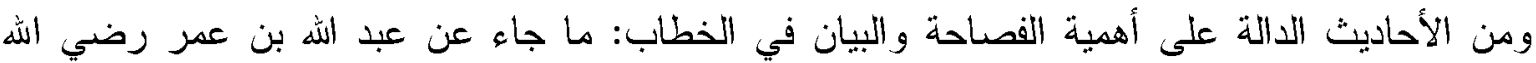

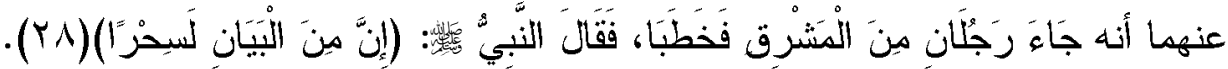

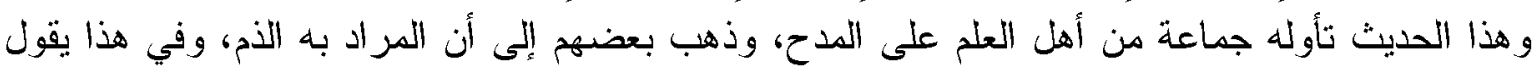

$$
\begin{aligned}
& \text { (Y) }
\end{aligned}
$$

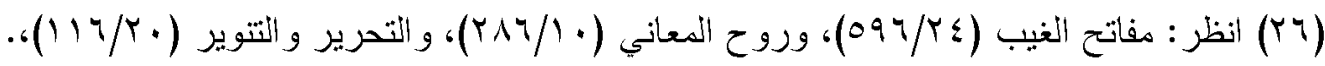

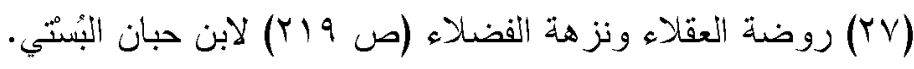

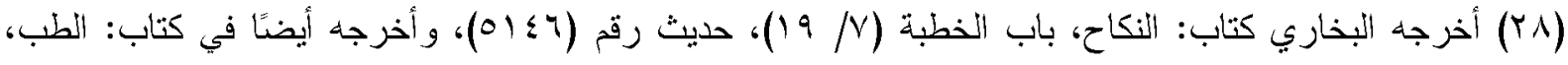

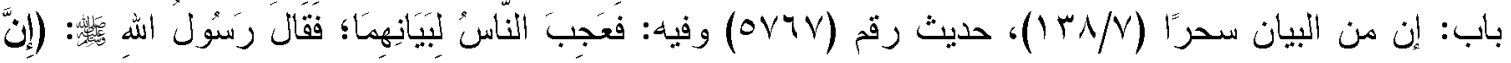

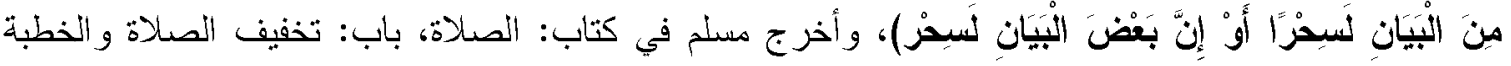

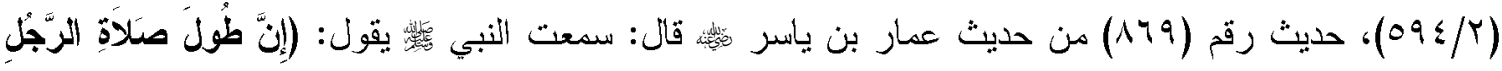

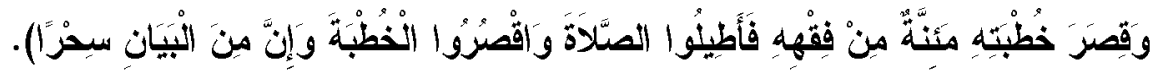




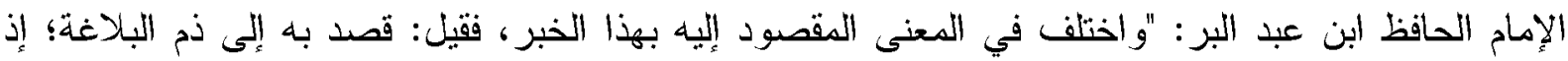

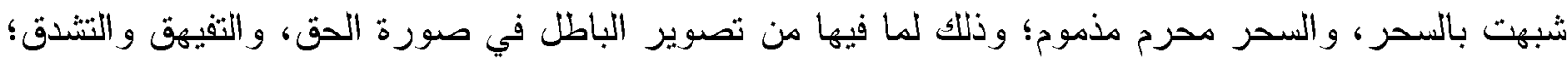

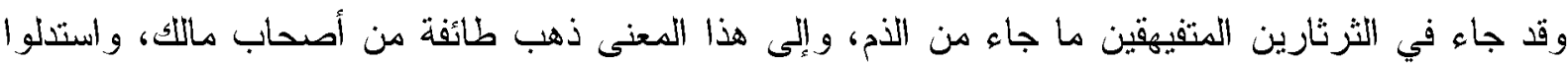

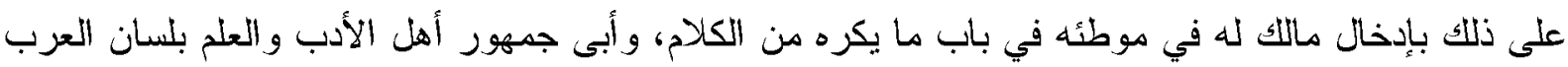

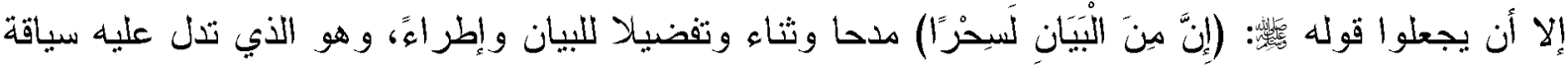

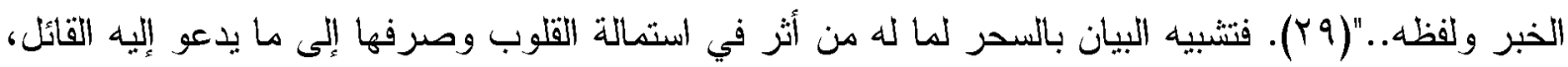
و السحر أصله الصرن. وقد قال عمر بن عبد العزيز لرجل سأله حاجة فأحسن المسألة، فأعجبه قوله فقال: "هذا واله السحر

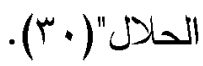

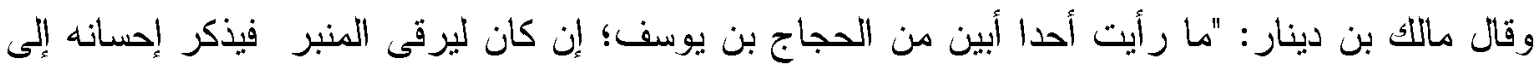

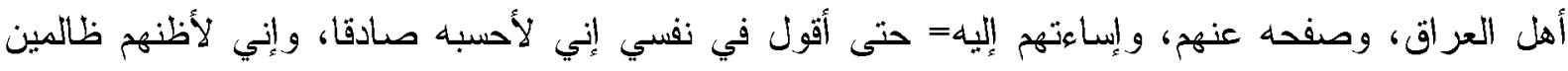

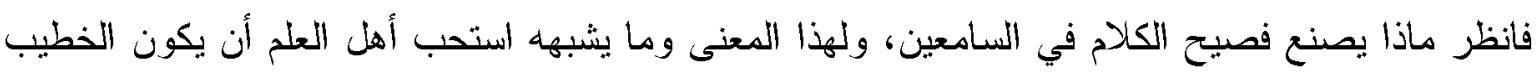

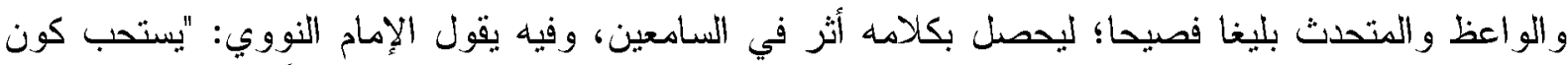

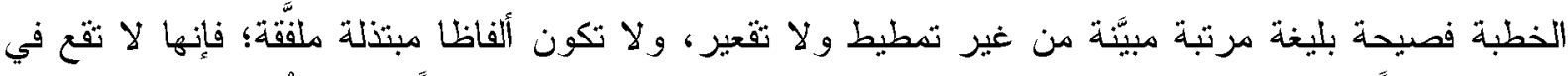

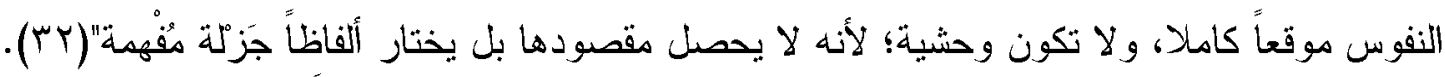

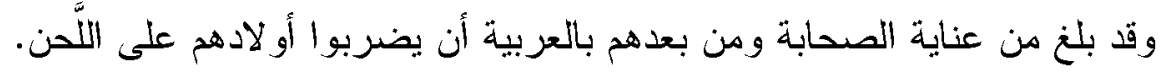

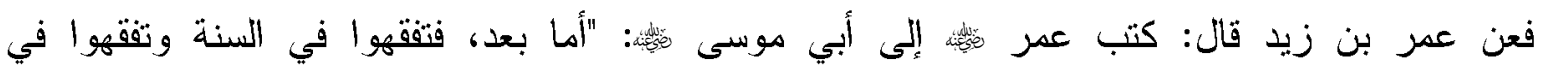

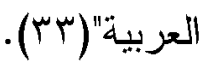

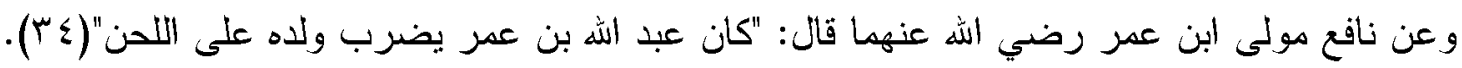

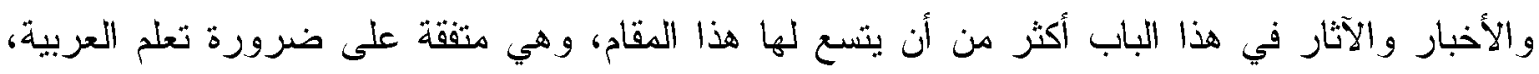

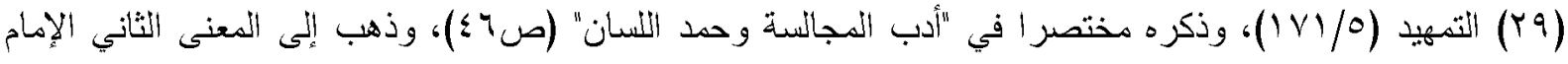

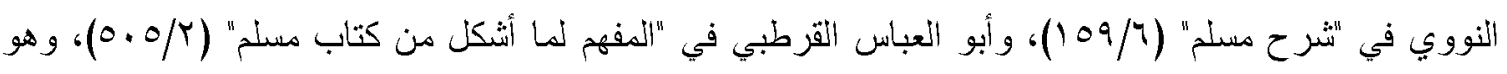
مذهب طائفة من الثر أح و أهل العلم.

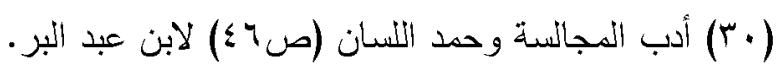

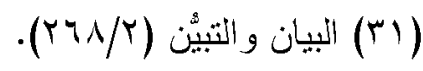

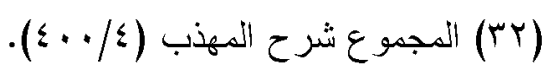

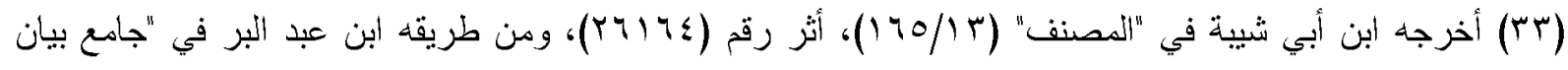

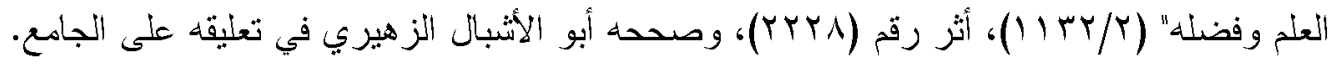

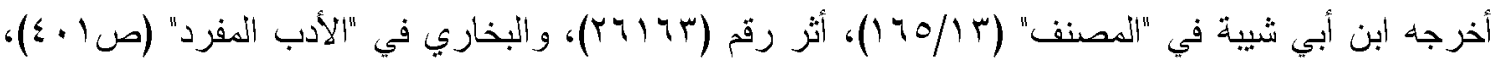

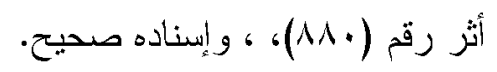


ولزوم الفصاحة و البيان، وأن المرء مهما تسلح بهذا السلاح في المحادثة و الدخاطبة كان لكلاده وقع، ولبيانه أثر ، و العكس بالعكس.

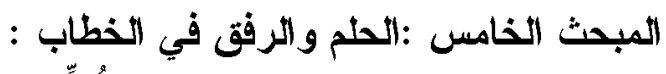

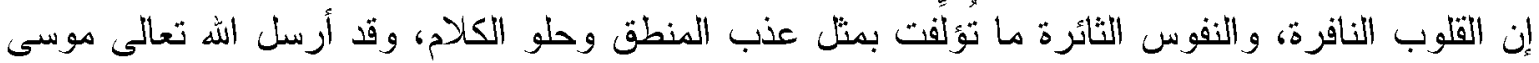

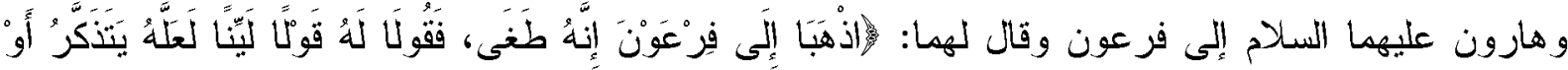

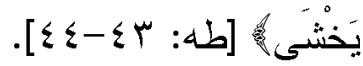

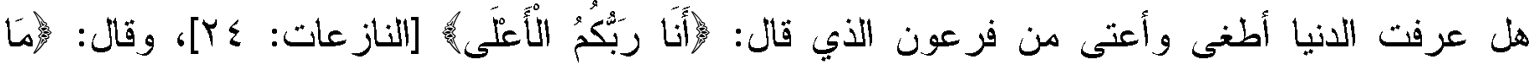

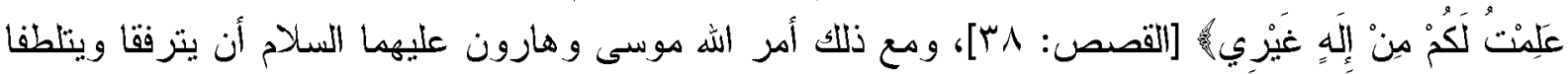

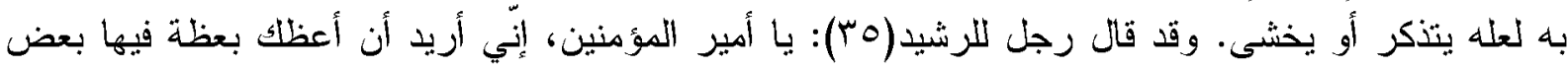

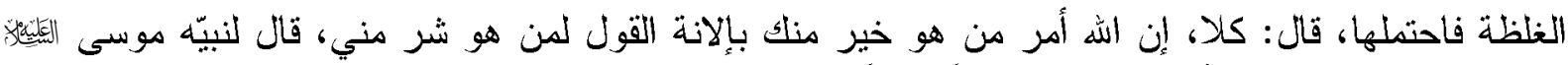

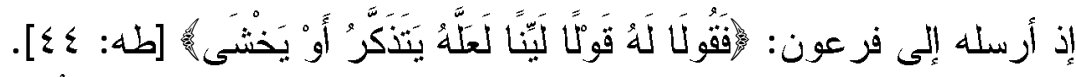

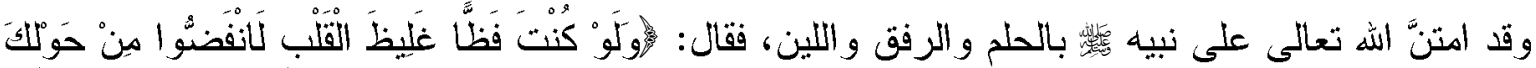

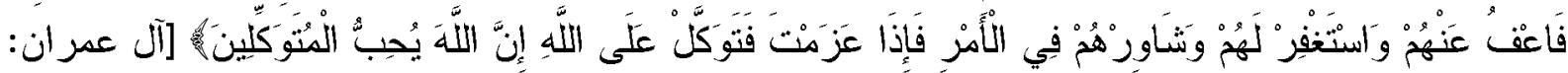

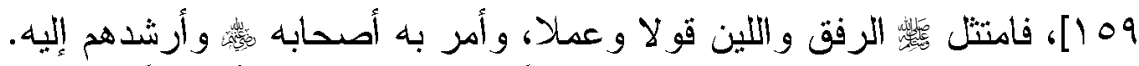

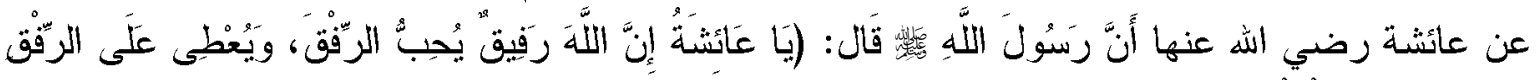

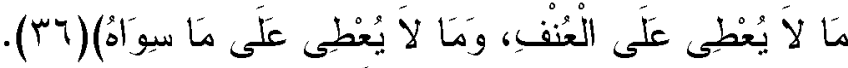

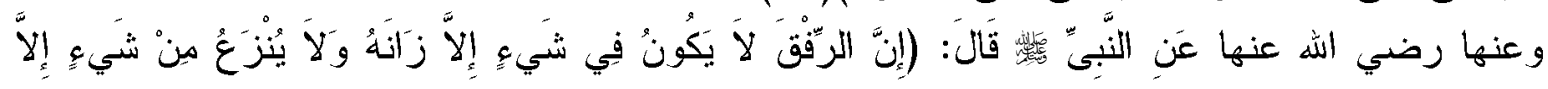

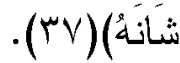

وما من شيءٍ أصدَّ للناس عن المتكلم من شدته وقسوته، فهي حجاب كثيف يحول بينهخ ويينه، وربما تعلل

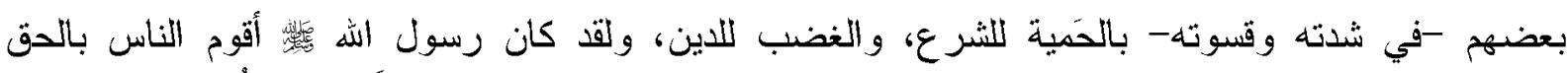

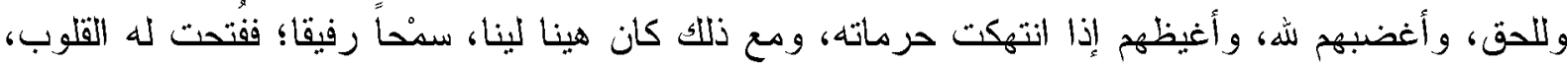
و وانقادت له النفوس.

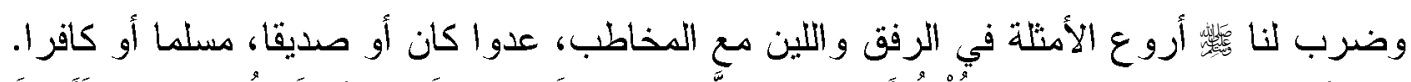

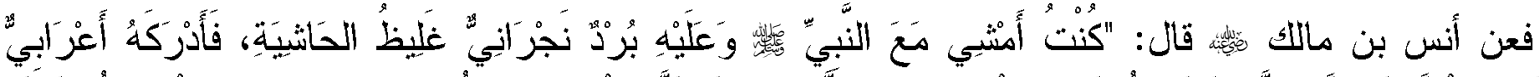

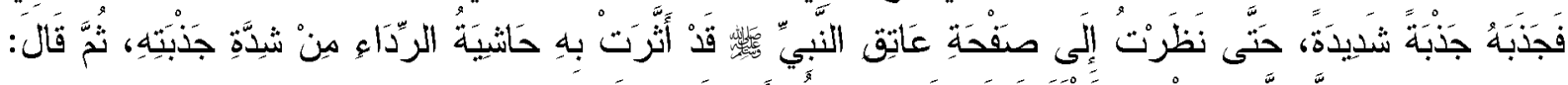

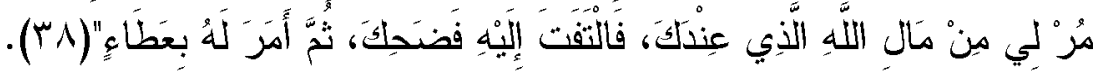

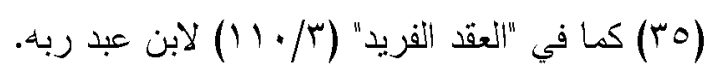

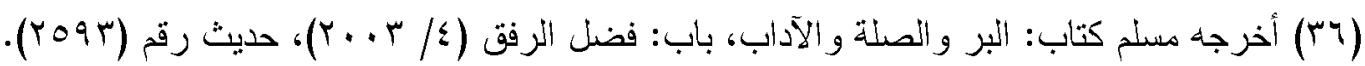

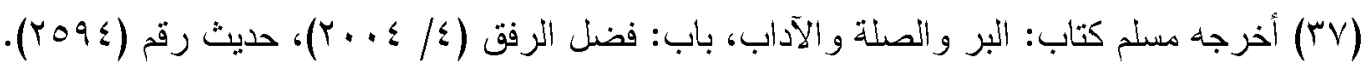

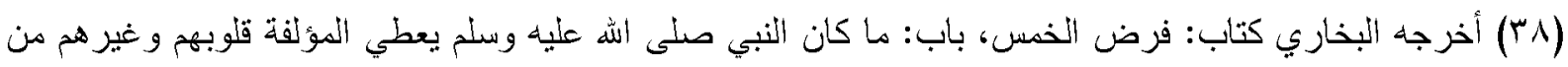

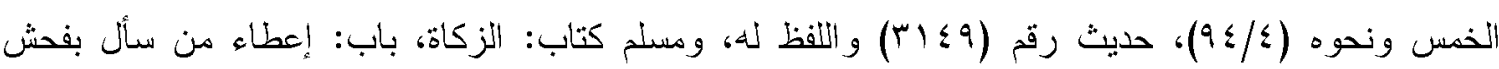

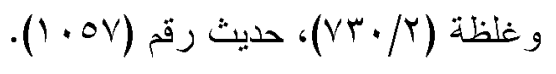




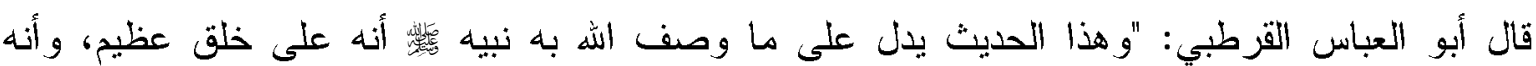

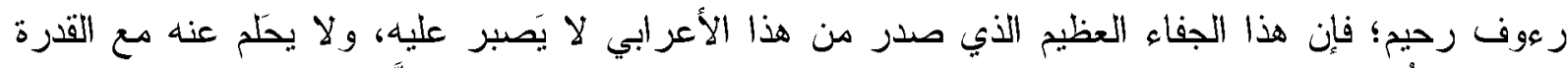

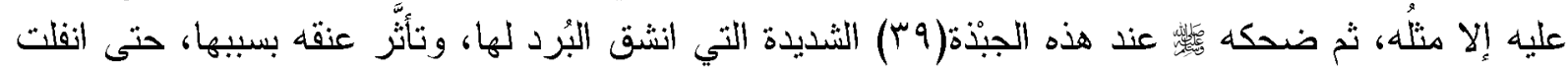

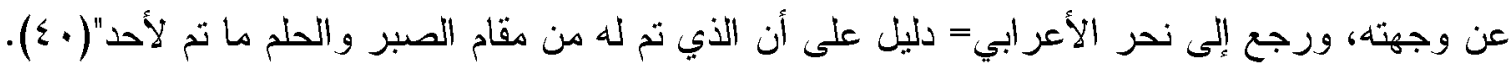

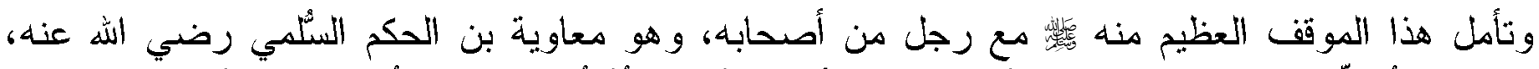

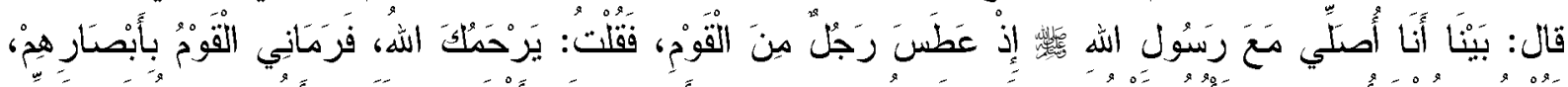

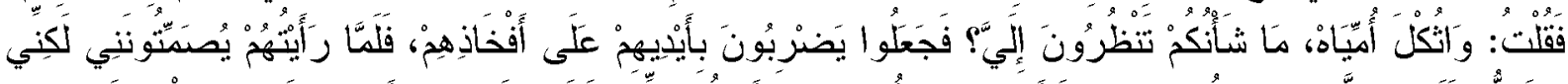

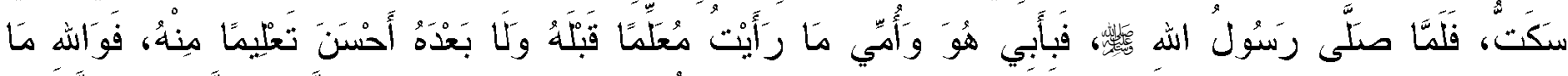

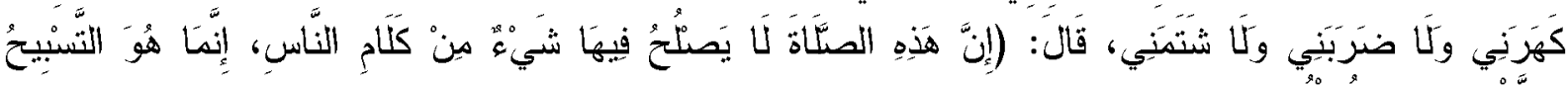

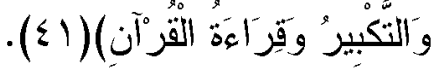

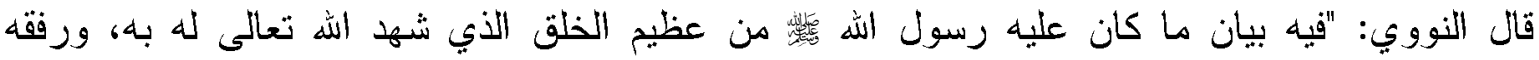

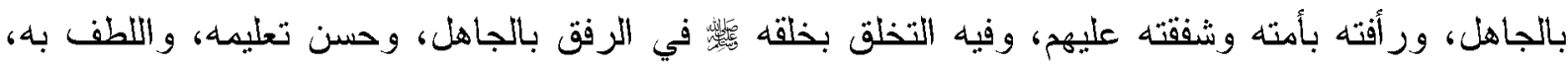

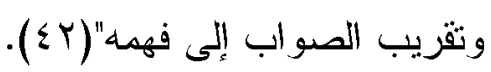

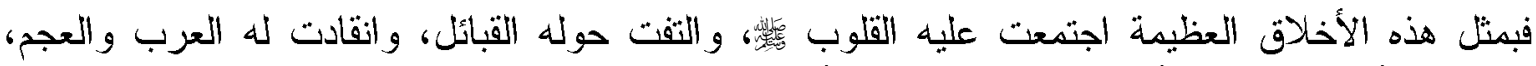

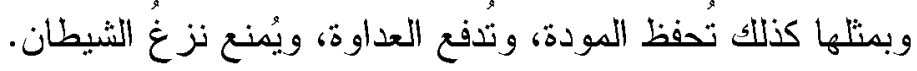

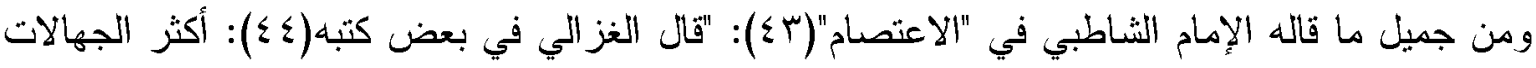

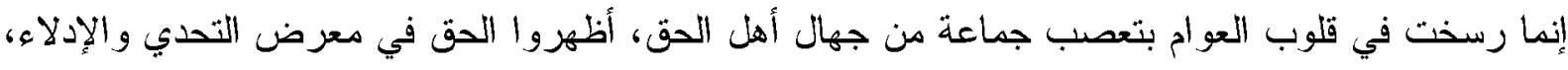

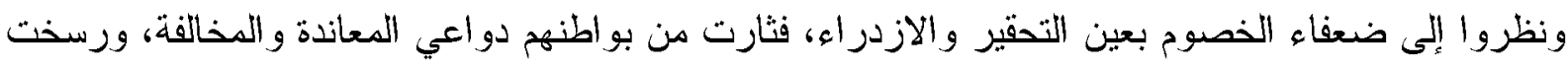

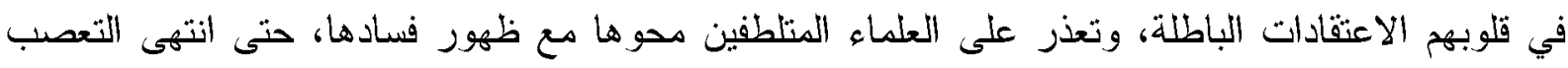

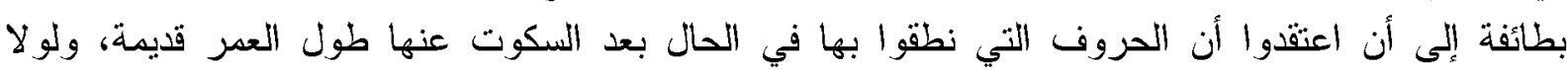

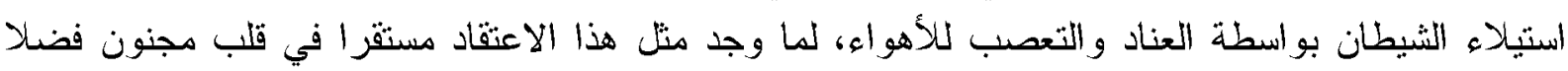

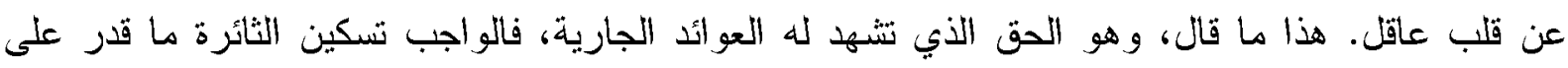

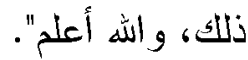

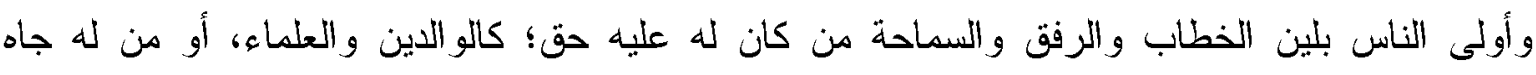

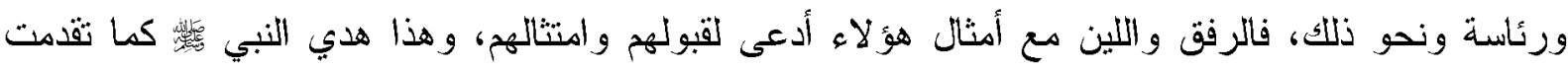

$$
\begin{aligned}
& \text { الجذب و الجبذ بمعنى واحد، وقد جاءت الروايات بهذا وذالك. }
\end{aligned}
$$

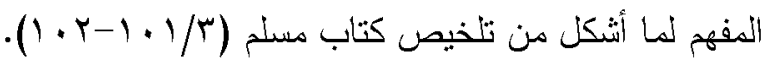

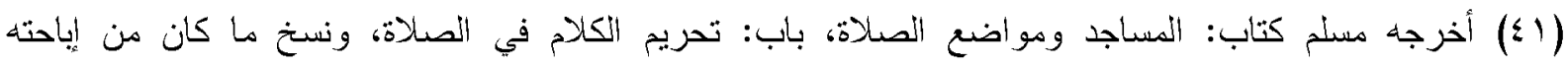

$$
\begin{aligned}
& \text { ) }
\end{aligned}
$$

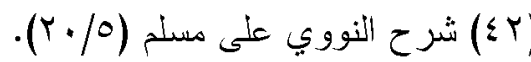

$$
\begin{aligned}
& \text { (1 }(17 / / \Gamma)(\leqslant r) \\
& \text { (؛ ؛) ولم أقف عليه في كتب الإمام الغزالي. }
\end{aligned}
$$




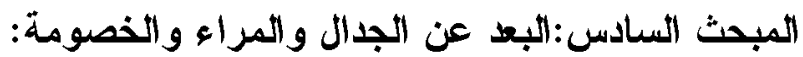

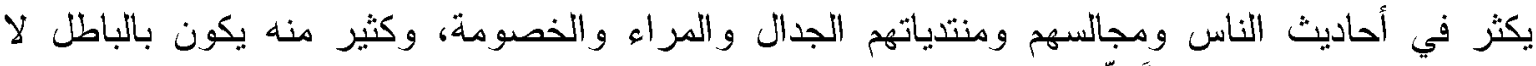

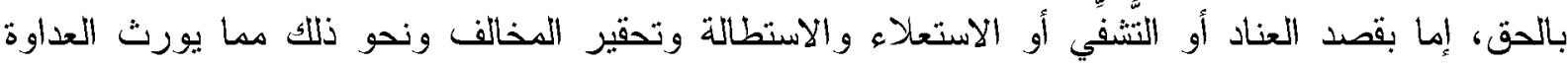
و البغضاء و الحقد في النفوس. بأسمان.

و أنقل للفائدة ابتداء كلام الإمام الغزالي في التفريق بين هذه الألفاظ، قال: "المراء: طعن في كلام الغير

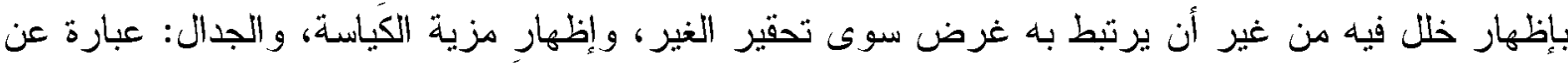

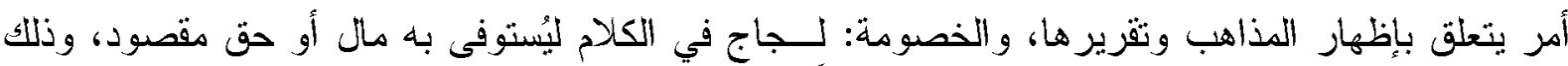

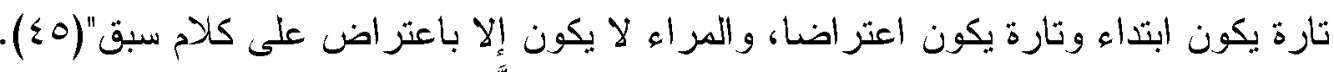
وقد عظم تحذير النبي

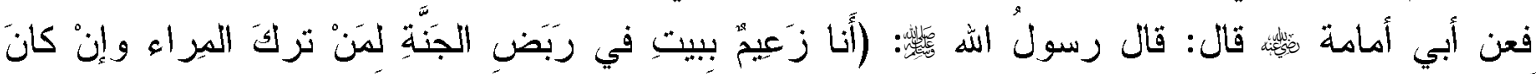

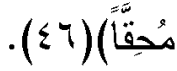

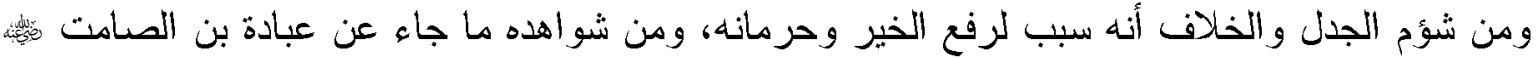

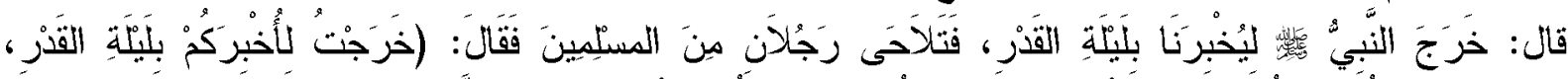

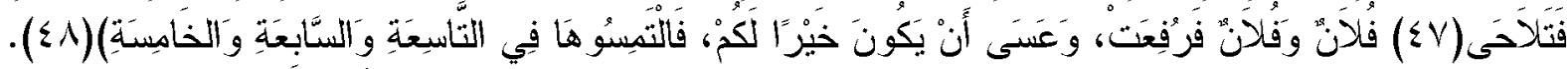

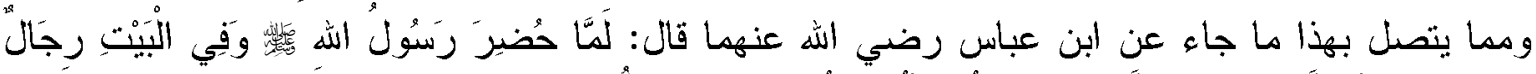

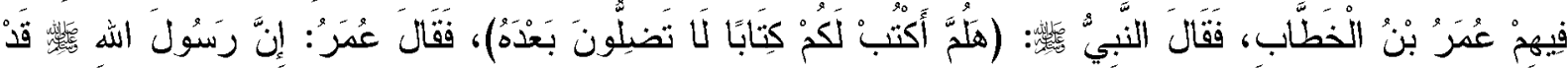

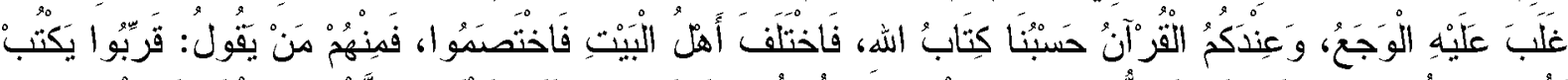

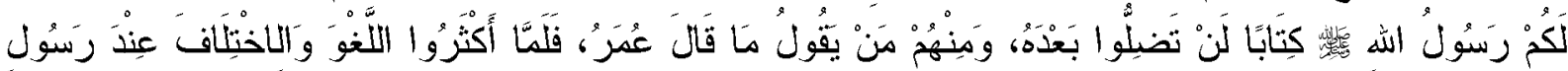

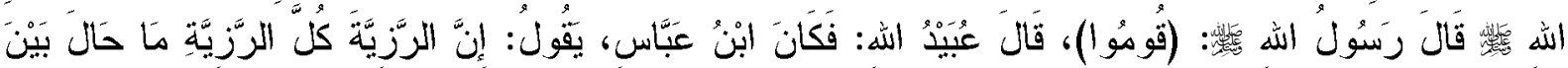

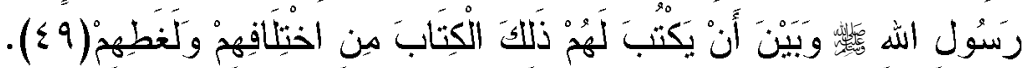
فانظر شؤم الخصومة والجدل و الخلاف كيف حُرم الصحابة بها معرفةَ لبلة القدر التي هي خير من ألف ونف

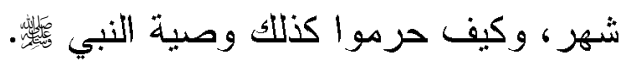
والجدال ليس مذموما بإطلاق، فمنه ما يكون محمودا، وهذا يختلف باختلاف نية المجادل، قال الإمام

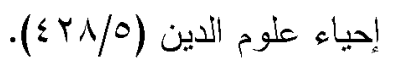

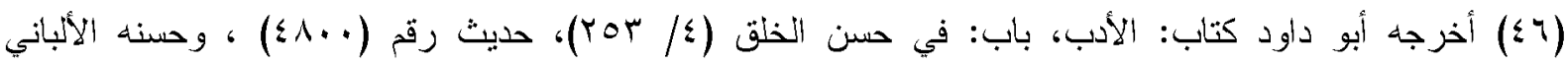

$$
\text { والأرنؤوط. }
$$

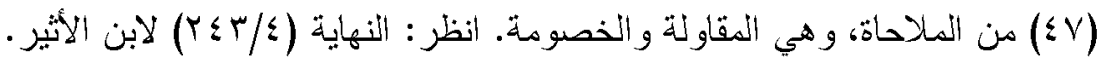

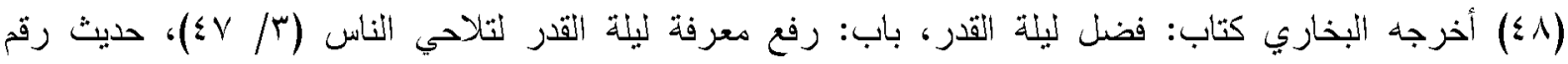

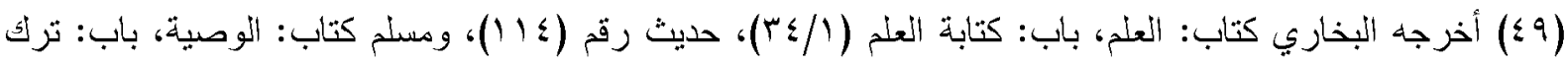

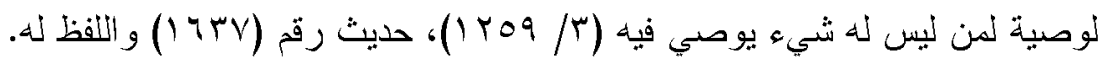




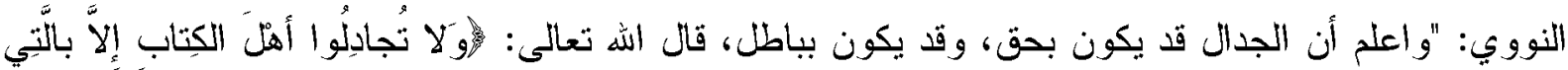

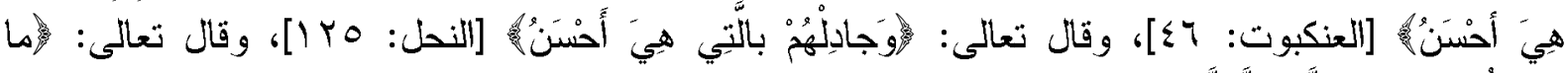

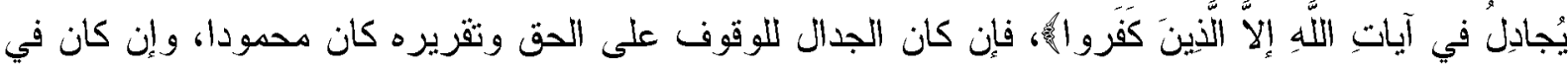

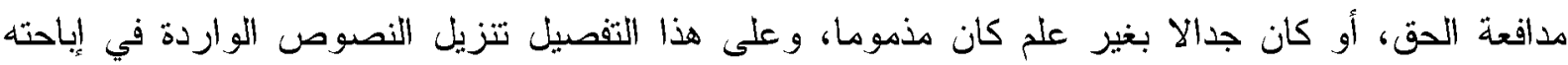

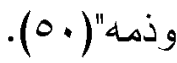

المبحث السابع : الإعراض عن اللثو وما لا فائدة فيه:

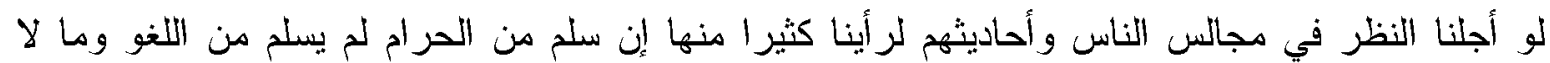

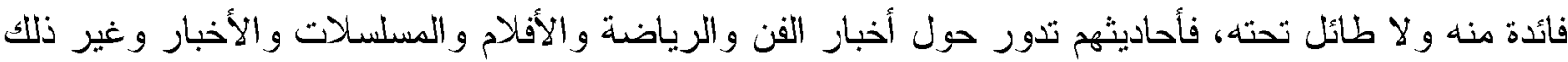

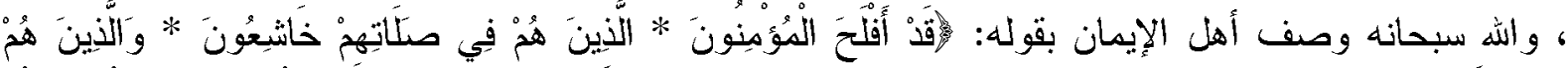

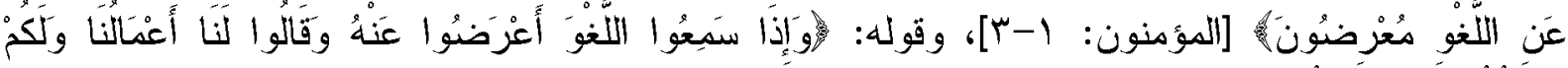

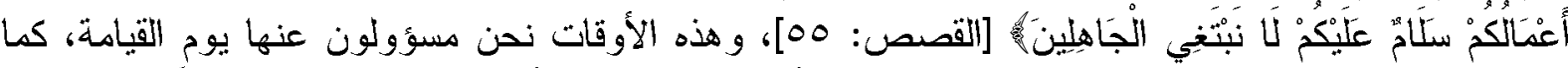

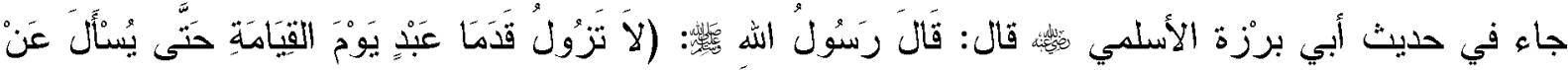

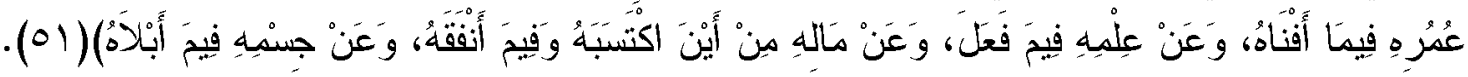

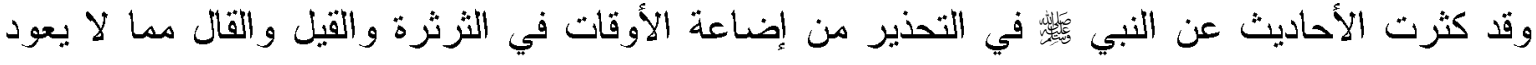

على صاحبه بعائدة ولا نفع في الانيا و الآخرة.

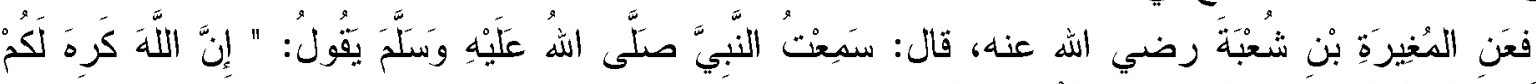

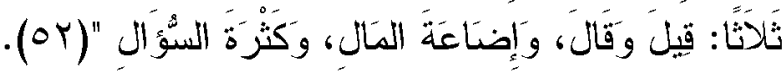

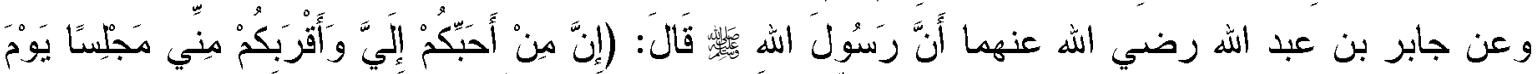

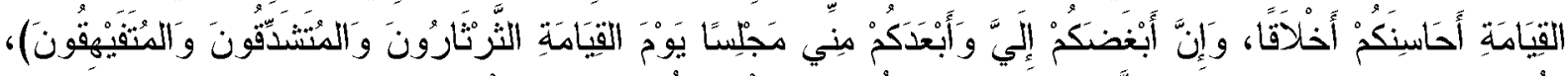

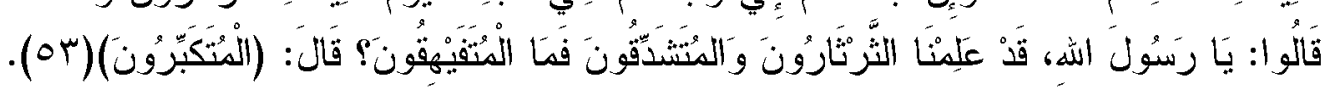

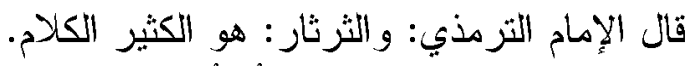

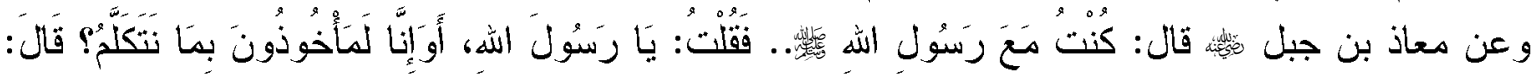

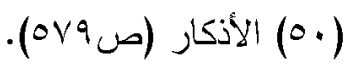

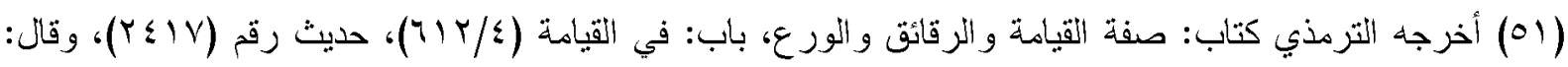

$$
\text { "حديث حسن صحيح". }
$$

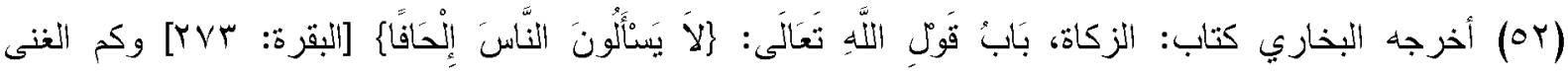

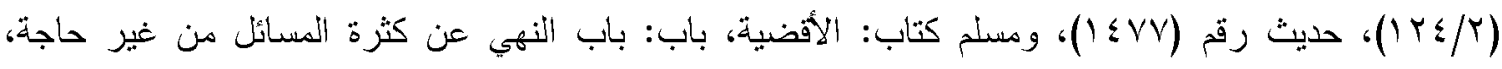

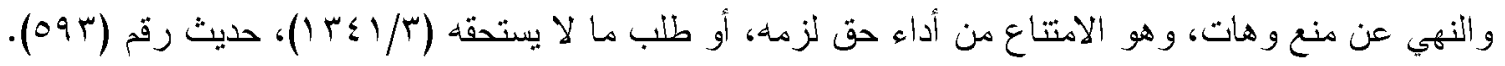

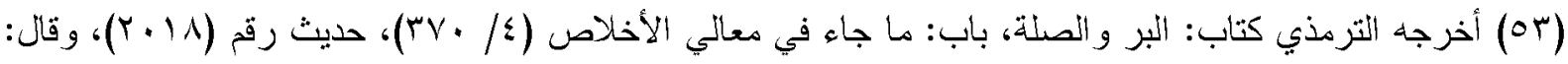

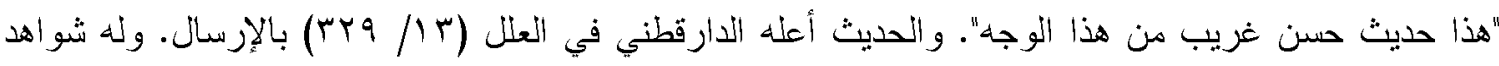

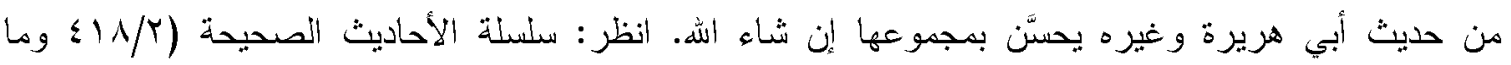
بعدها) للثيخ الألباني، و الله أعلم. 


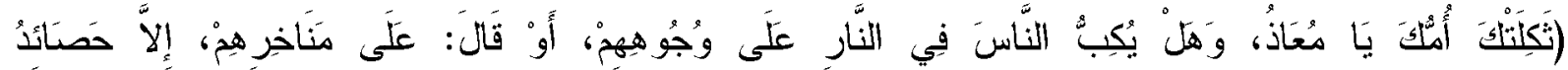

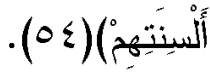

والأحاديث في الباب كثيرة ليس الغرض استيفاءها هنا، وكذا وردث آثارًا عن الصحابة والتابعين في هذا

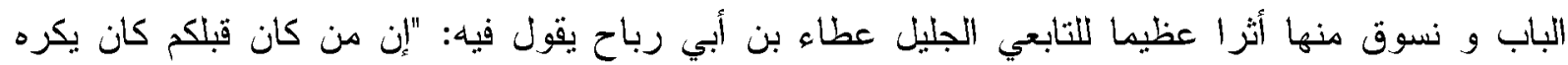

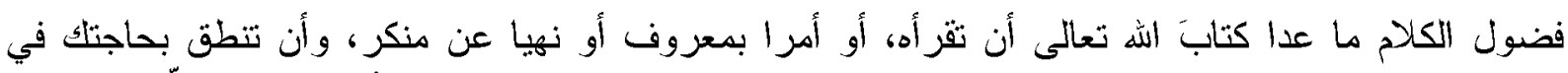

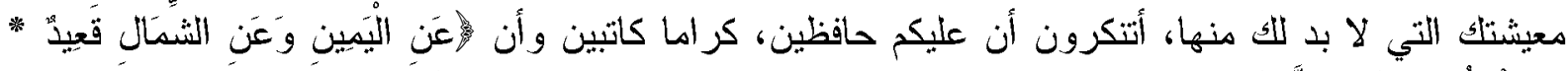

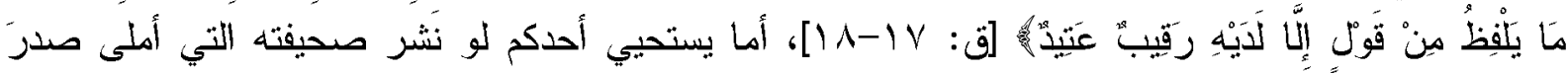
نهارهو أكثرُ ما فيها ليس من أمر دينه و لا دنياه"(00).

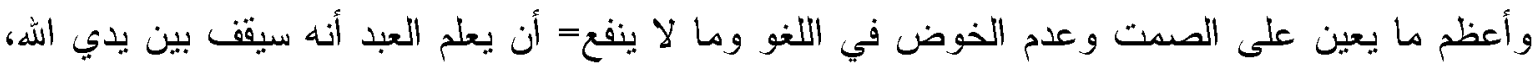

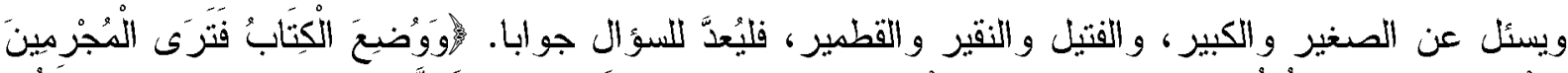

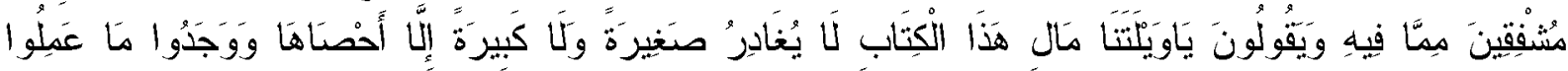

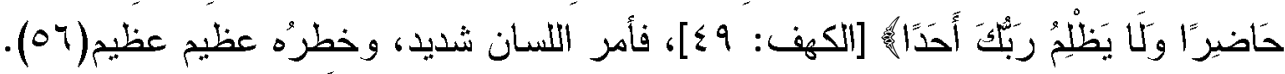

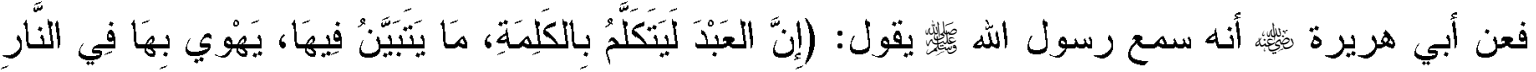

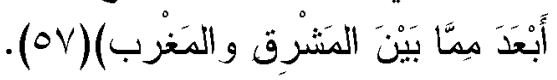

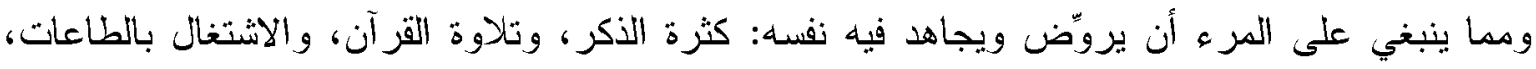

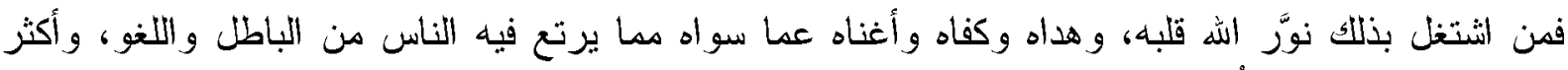

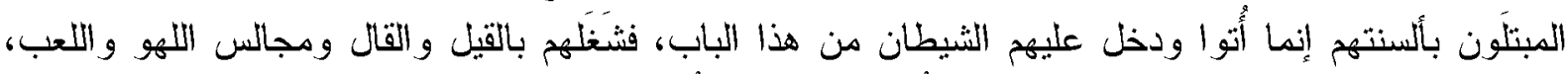

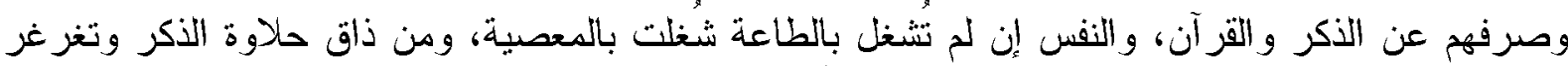

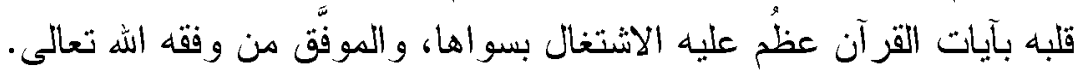

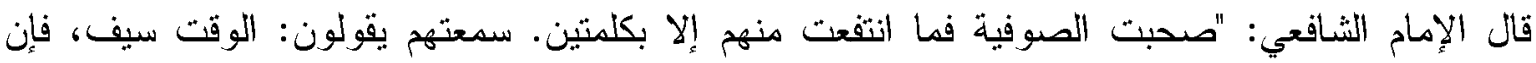

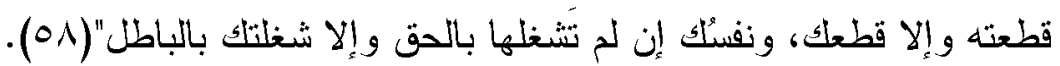

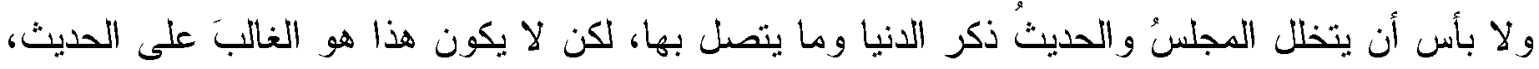

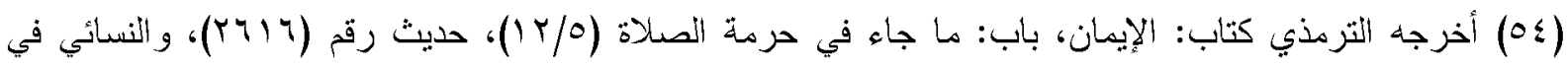

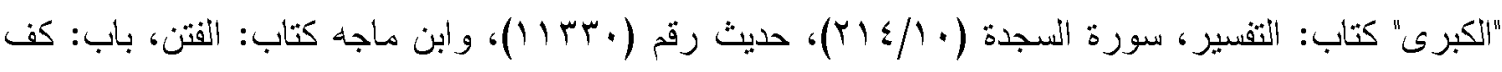

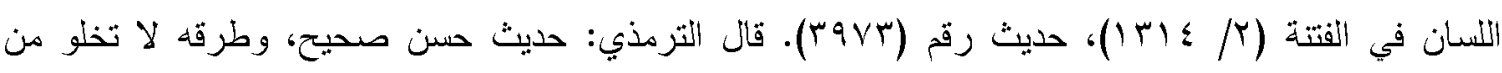

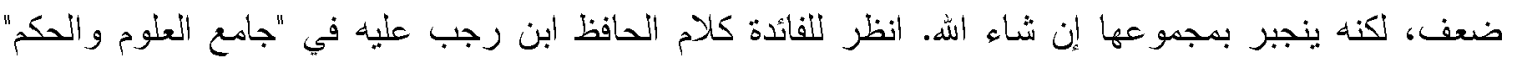

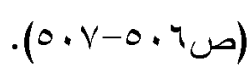

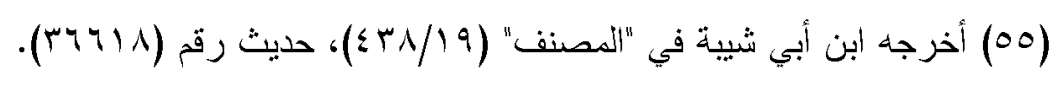

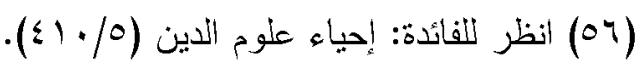

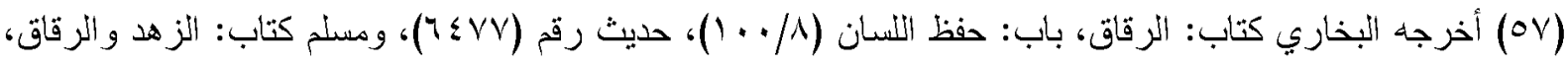

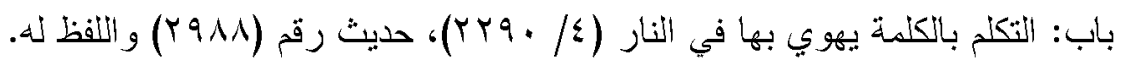

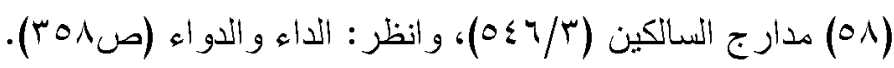




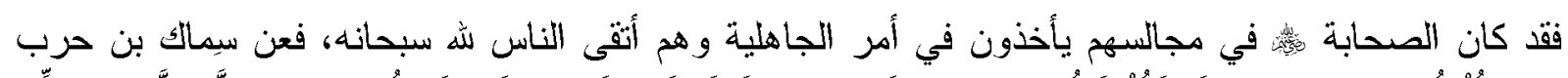

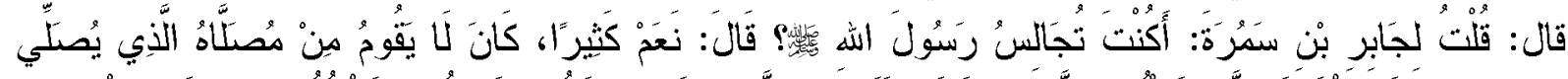

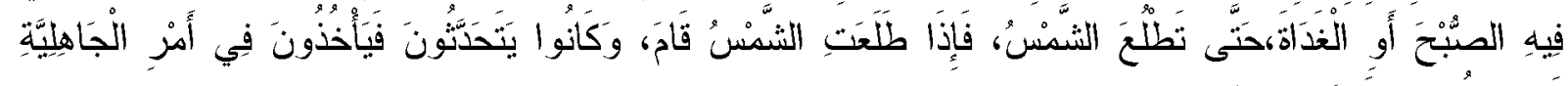

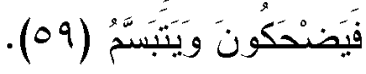
قال الإمام النووي في "شرحه على مسلد"(. آ): "فيه جواز الحديث بأخبار الجاهلية وغيرها من الأمم وجواز الضحك". وما أحسن ما قاله الإمام النووي في "الأذكار"(آ()، و أختم به، قال: "اعلم أنه لكل مكلف أن يحفظ لسانه

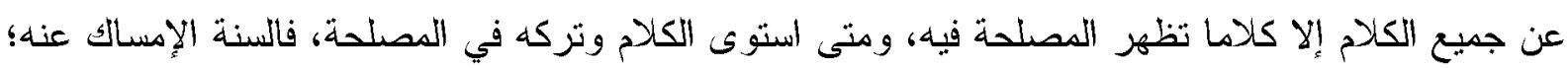
لأنه قد ينجر الكلام المباح إلى حرام أو مكروه، بل هذا كثير أو غالب في العادة، و السلامة لا بعدلها شئ.

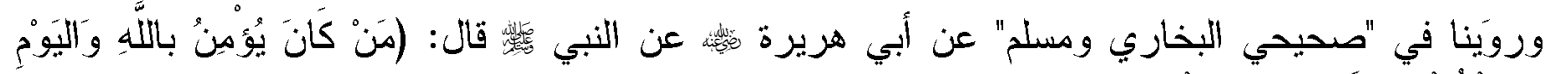

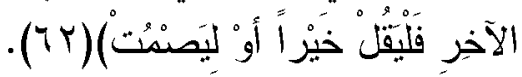
قلت: فهذا الحديث المتفق على صحته نص صريح في أنه لا ينبخي أن يتكلم إلا إذا كان الكلام خيرا، وهو الأي ظهرت له مصلحته، ومنى شك في ظهور المصلحة فلا يتكلم".

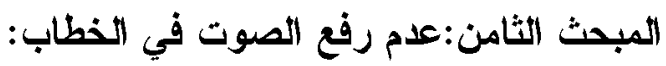

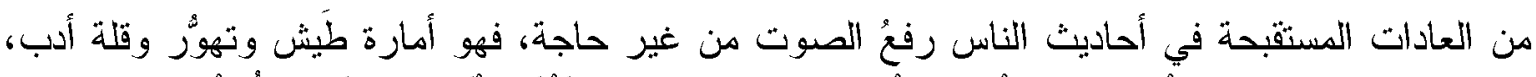

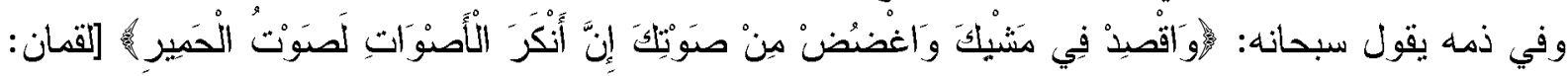

قال عبد الرحمن بن زيد بن أسلم: "لو كان رفعُ الصوت هو خيرٌ ما جعله للحمير"(بآ).

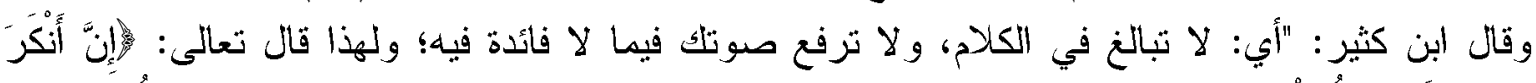

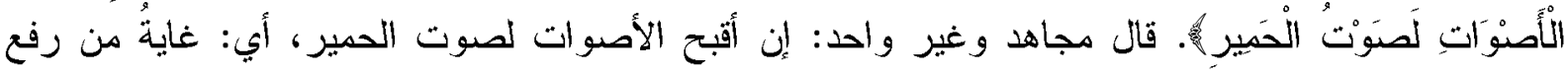

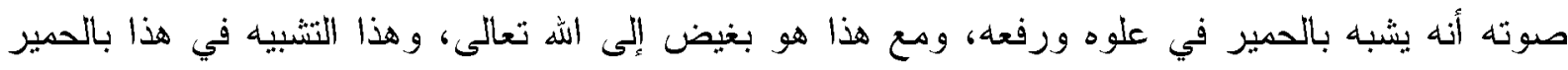
يقتضي تحريمه وذمَّه غاية الذم" (ع ب). وأكثر ما يكون هذا مستقبحا في الأماكن المعظمَّة المحترمة؛ كالمساجد ومجالس العلم والذكر ونحو ذلك،

(1) أخرجه مسلم كتاب: المساجد ومواضع الصلاة، باب: فضل الجلوس في مصدلاه بعد الصبح، وفضل المساجد (1)

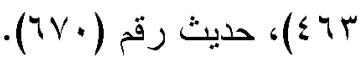

$$
\begin{aligned}
& .(19 / 10)(7 .) \\
& \text { (ص) (1) (1) (1) }
\end{aligned}
$$

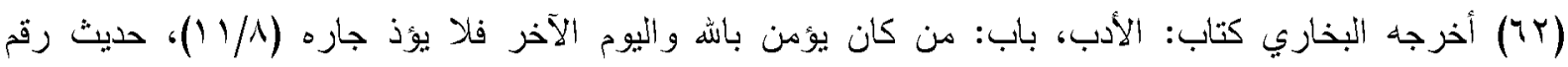

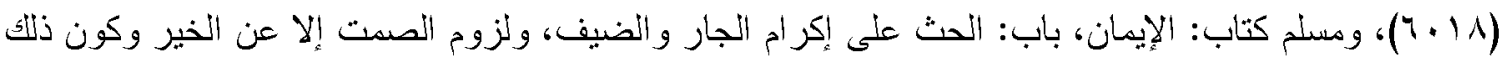

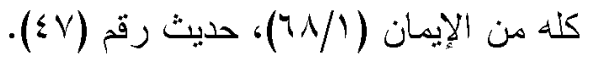

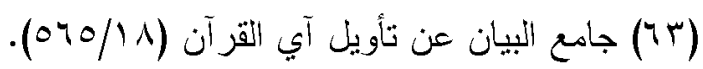

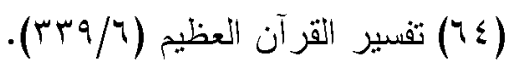


فهذه ينبخي أن تُشى بالسكينة و الجلال، و الأدب و الوقار ، و لا يليق فيها التصايح و الصنّخَب. وقد بوَّب البخاري

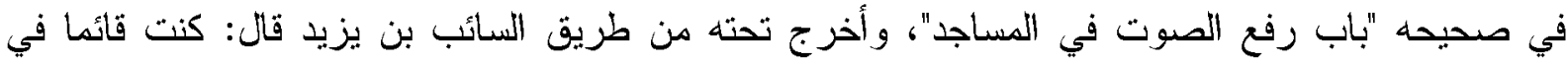

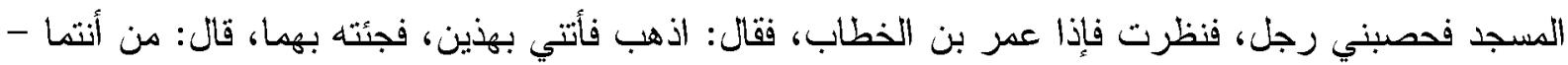

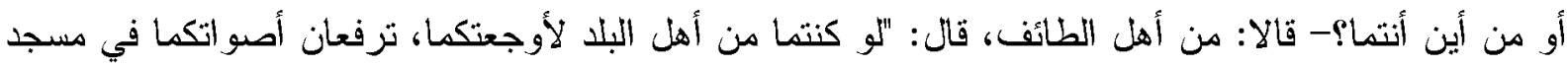

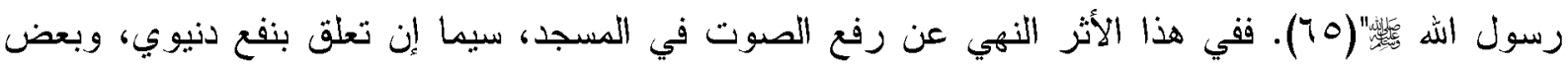

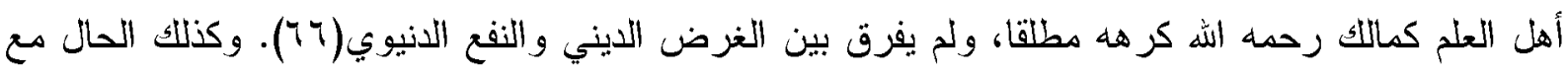

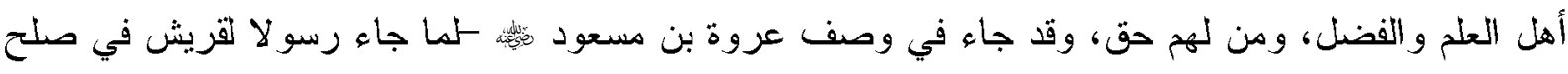

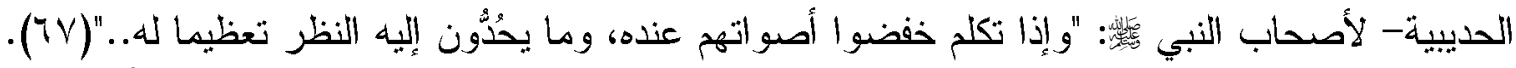

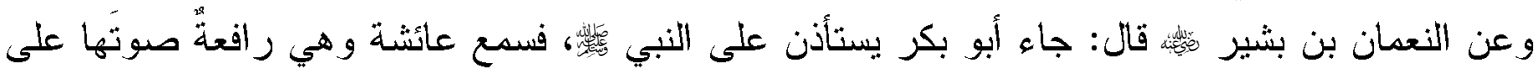

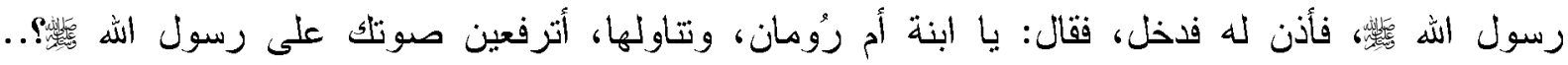

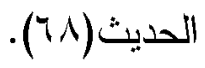

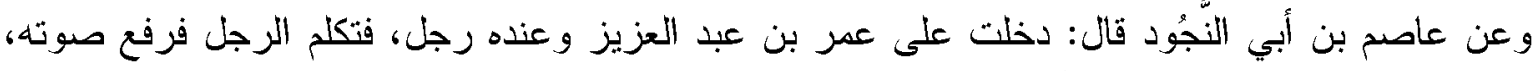

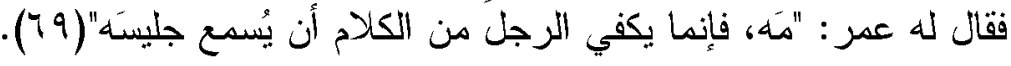

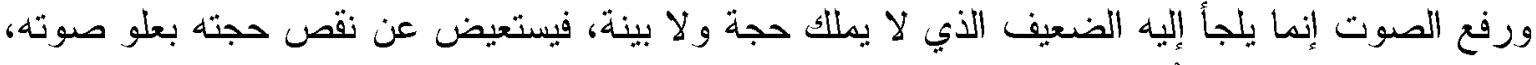

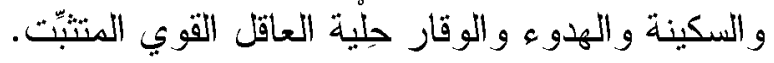

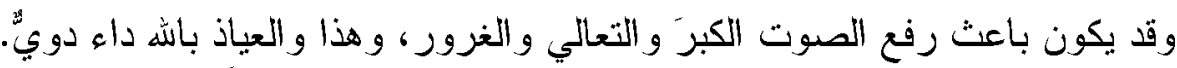

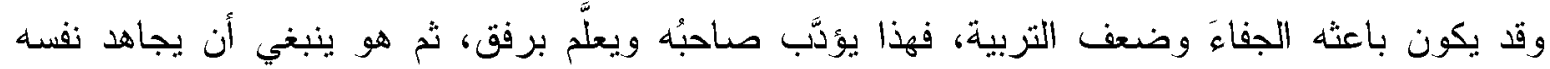

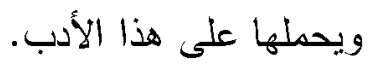
وبالجملة فهذا الأدب من الآداب العظيمة التي تغافل الناس عنها، وفشا فيهم نقيضهُها، فينبغي أن يُحرص

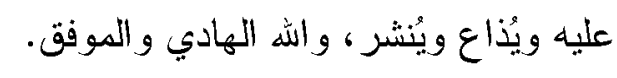

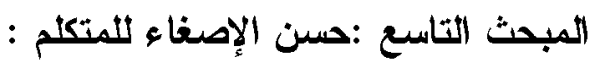
أكثر الناس يجيدون الحديث أكثر مما يجيدون الاستماع، فترى الرجل يتكلم ساعة ولاع يحتمل سماع أخيه دقيقة. والإقبال على المتحدث، ورعاية حديثه بالإنصات وحسن الاستماع من أهم آدب التخاطب، وليس من

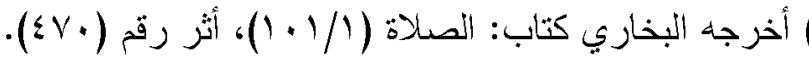

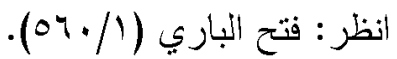

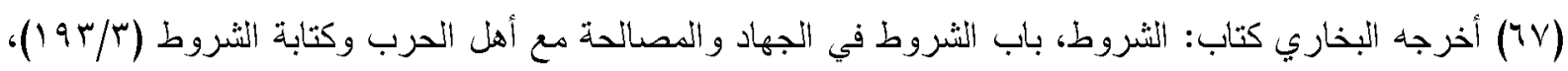

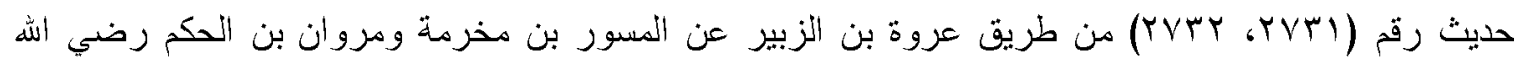

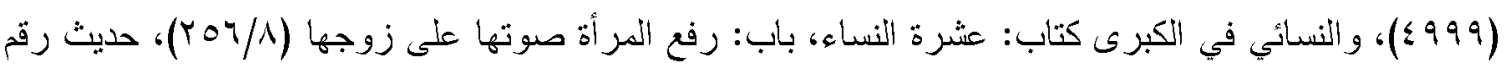


الأدب و لا المروءة أن تتشاغل عمن يحدثك، و لا تباليَ بحديثه، إنك إذا لمن الجاهلين. و الناس في هجر ذالك الأدب لهم طر ائق مختلفة:

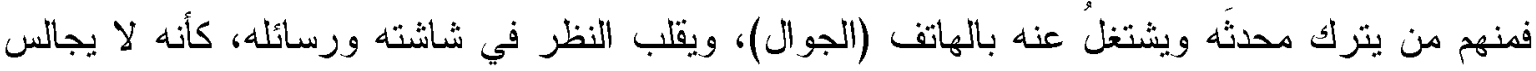

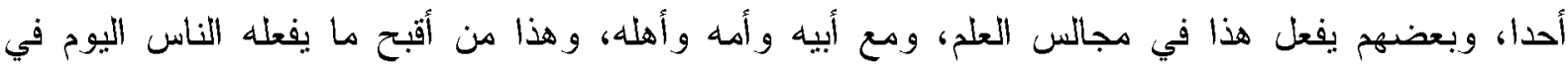
المجالس.

و منهم يبادرك الحديث، فما أن تذكر كلمة أو حديثا إلا وبادر بإظهار اطلاعه عليه ومعرفته به جهلا وتعالما و وغرورا.

ومنهم من يقطع عليك حديتك كلما عنَّ له فكره، أو انقدح في ذهنه شيء مدا يتصل بحديثك، فلا يكاد المتحدث يُتم جملة حتى يقفز هذا الأحمق لقطع حديثه.

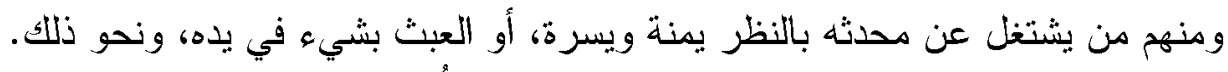

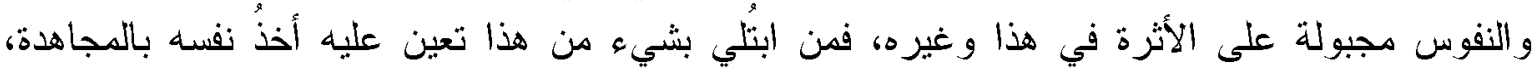

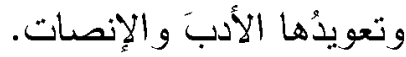

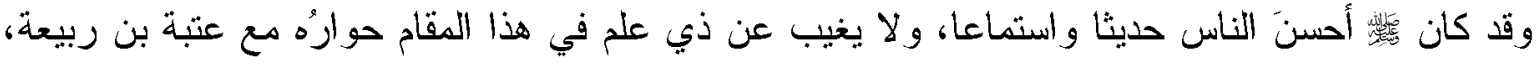

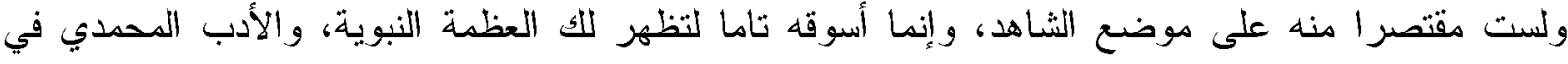

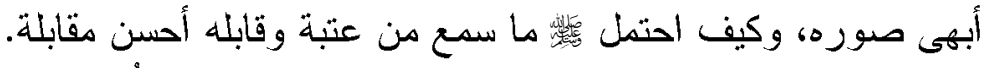
أسند ابن إسحاق في سيرته من طريق محمد بن كعب القرظي قال : قال حُّنتّت أن عتبة ابن ربيعة كان سيدا

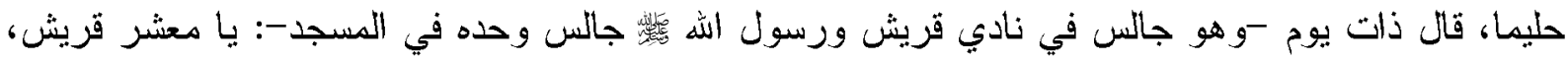

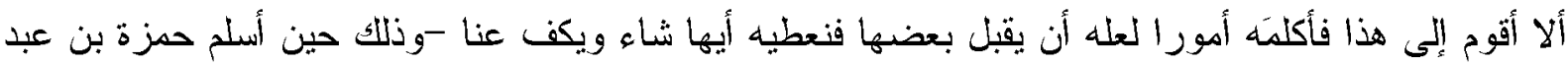

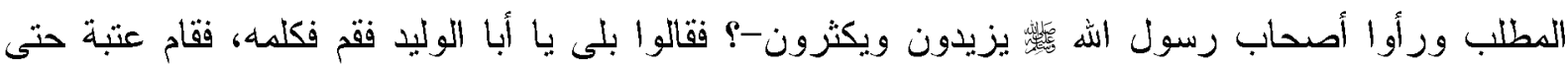

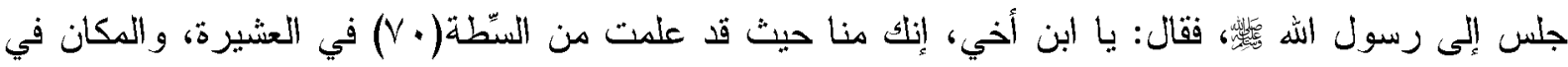
النسب، وإنك قد أتيت قوملك بأمر عظيم؛ فرقت به جماعتهم، وسفهت بـ أحلامهز، وعبت بـه آلهنه ودينهخ،

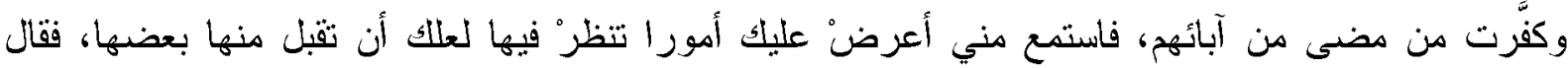

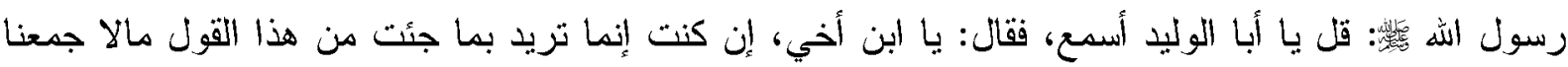

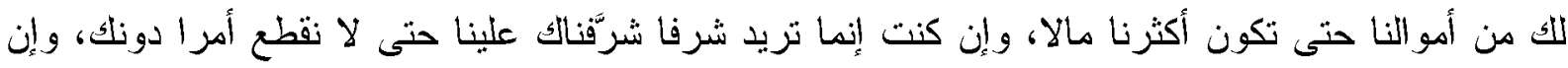

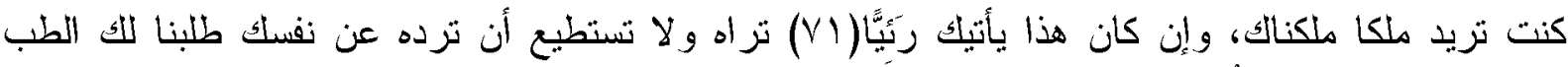

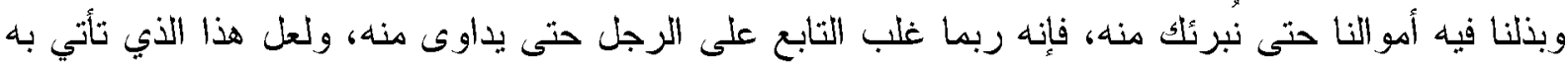

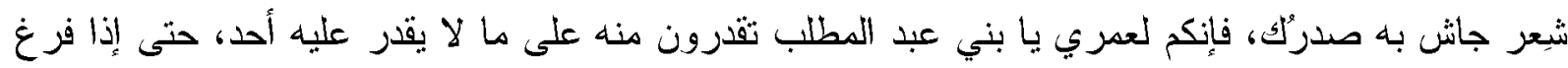

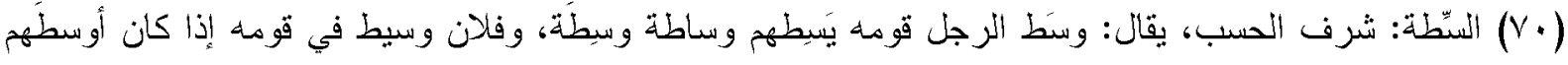

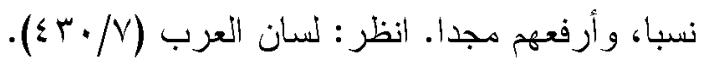

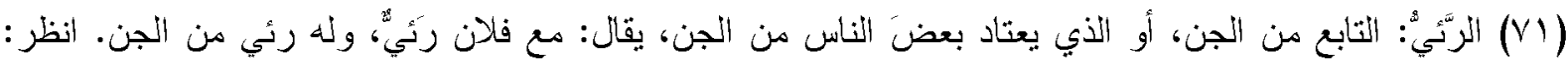

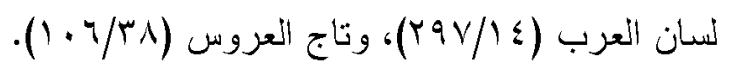




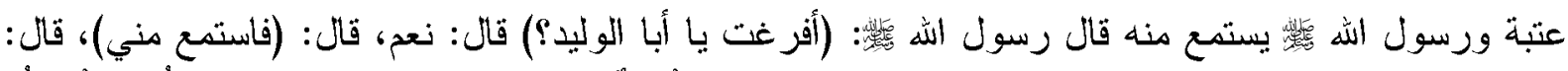

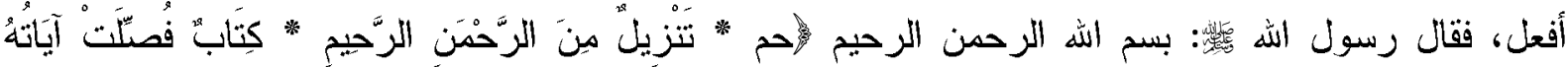

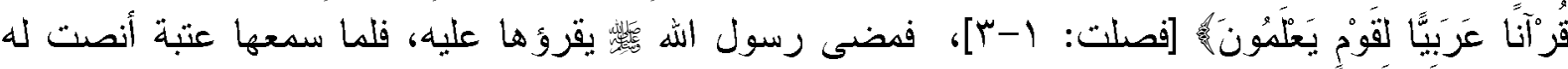

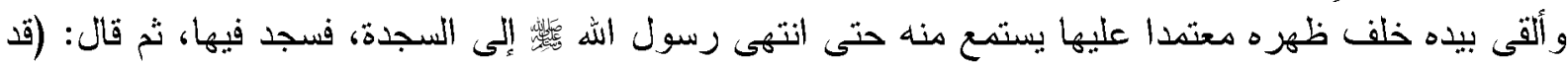

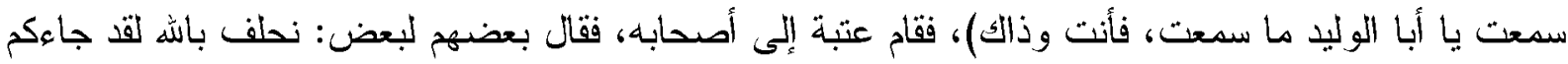

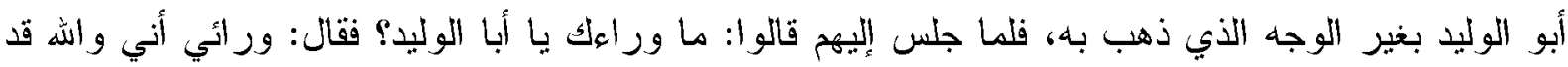

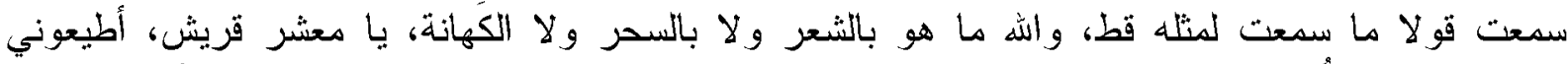

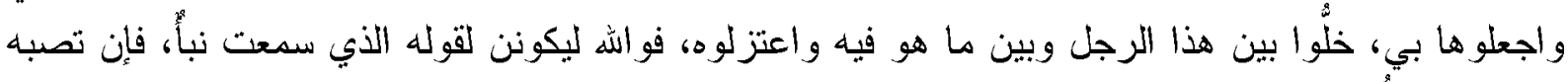

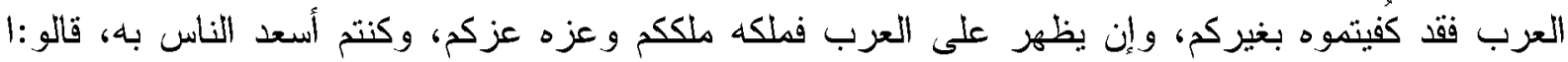

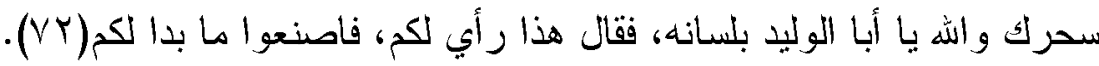

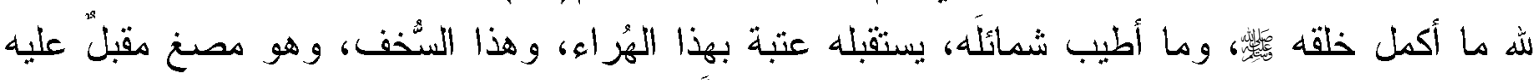

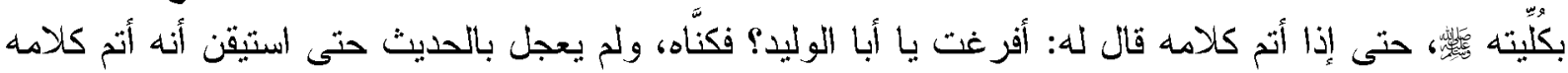

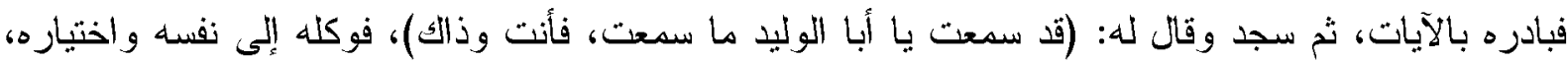

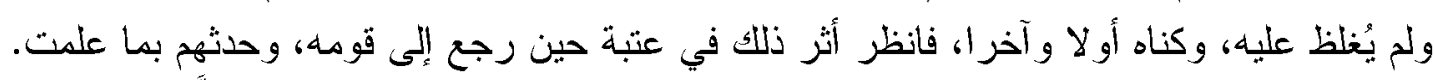

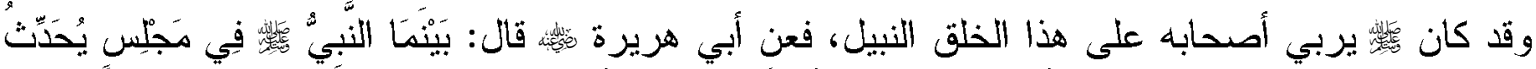

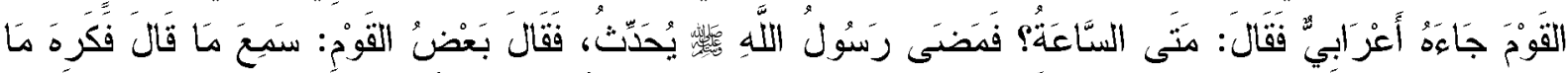

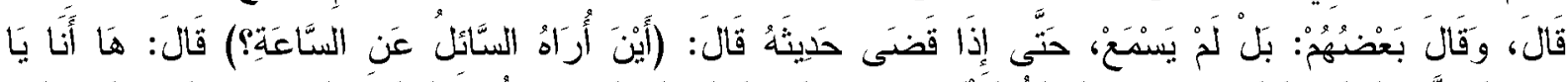

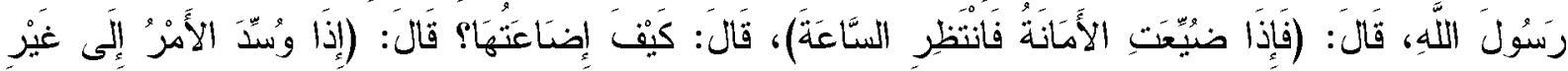

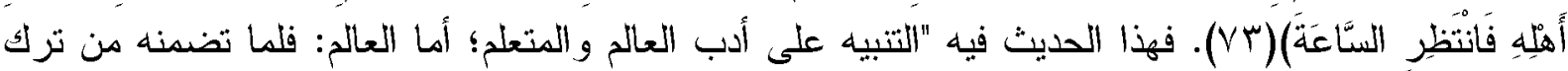

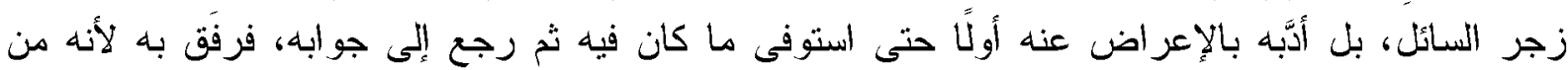

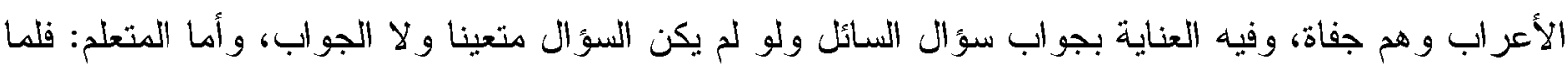

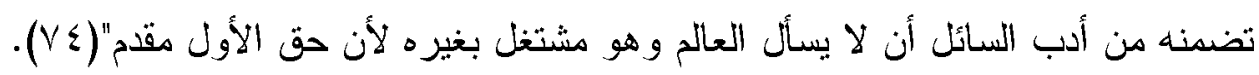

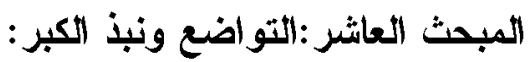

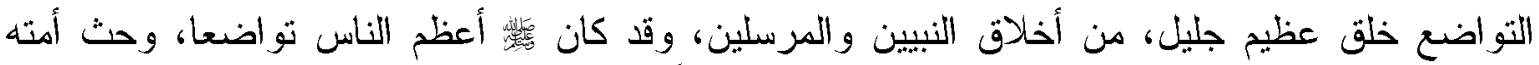

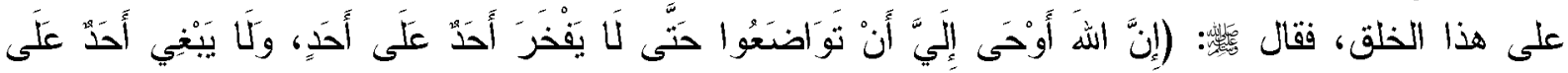

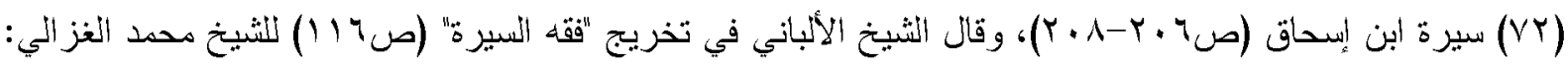

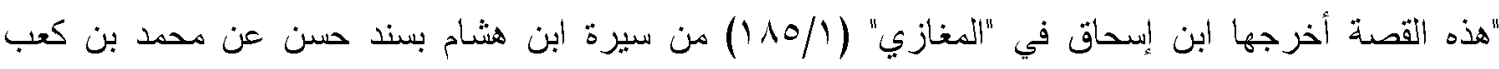

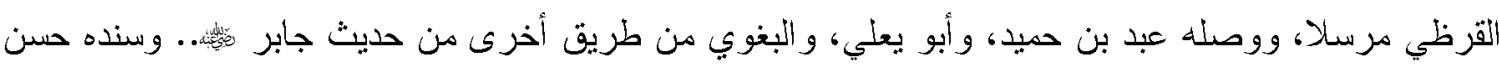
إن شاء الله".

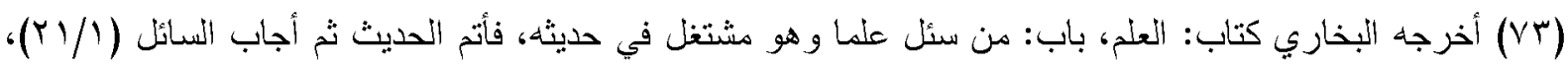

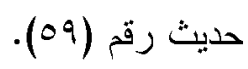

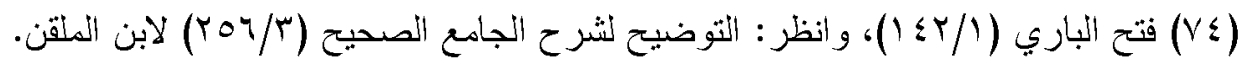




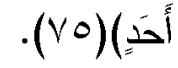

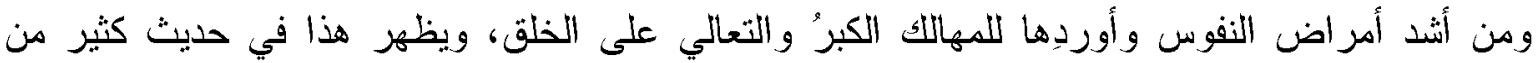

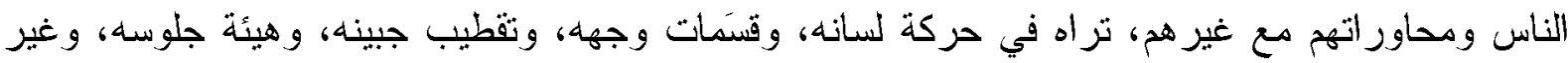

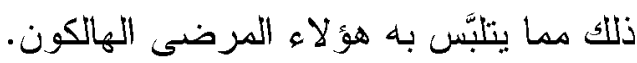

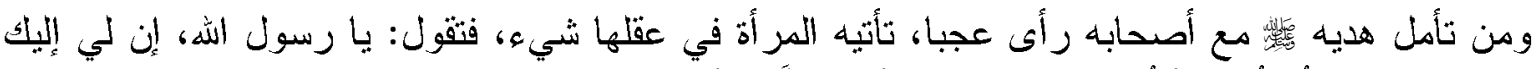

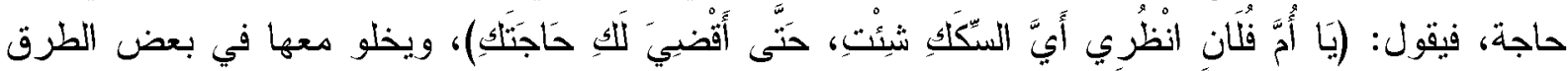
حتى يقضي حاجتها (VT) (VT) ويأتيه الرجل الغريب لكي يتعلم دينه فيقلبل عليه ولا ينشغل عنه صلى اله عليه وسلم، كما في حديث أبي

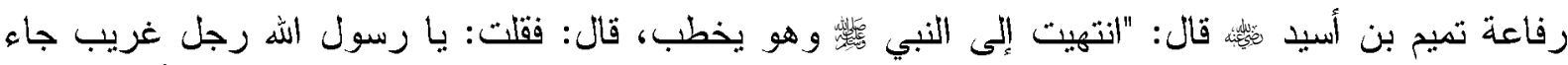

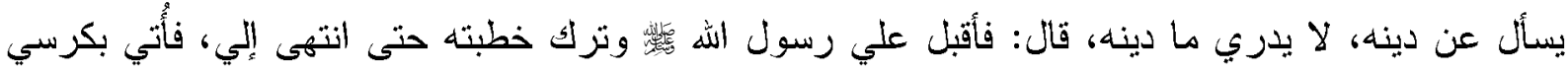

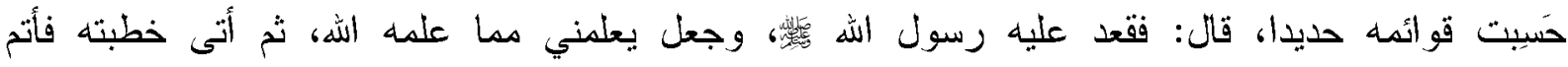

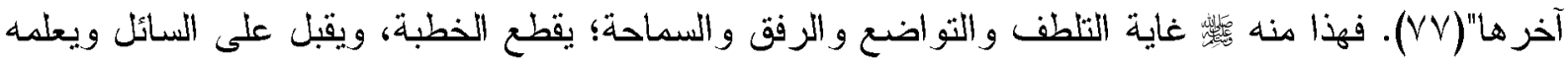

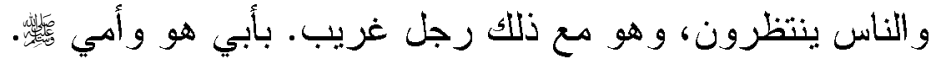

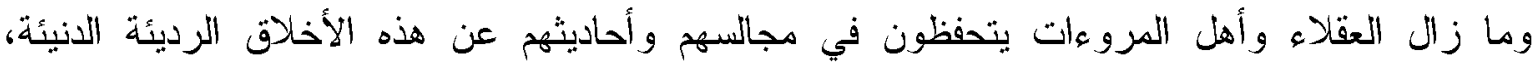

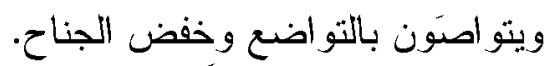

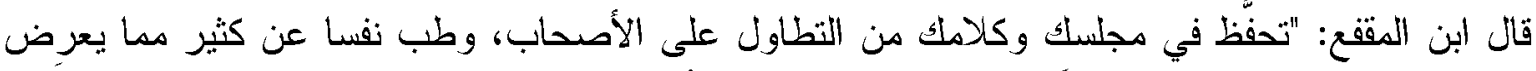

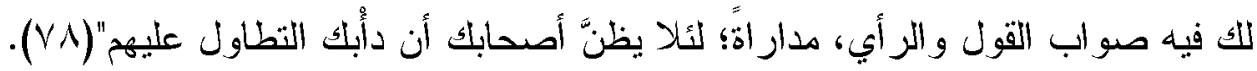

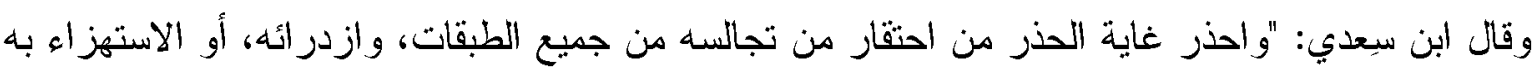

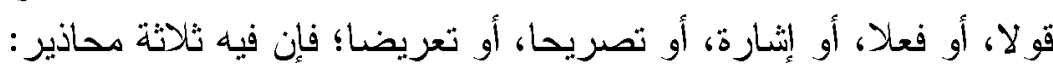

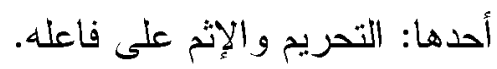
الثاني: دلالته على حمق صاحبه، وسفاهة عقله وجهله الأله

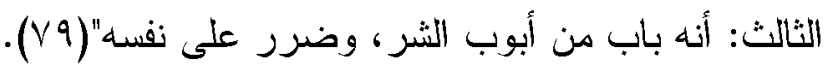

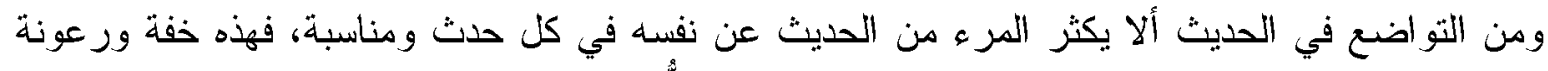

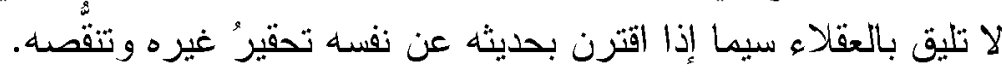

(Vo) أخرجه مسلم كتاب: الجنة وصفة نعيمها وأهلها، باب: الصفات التي يعرف بها في الأنيا أهل الجنة وأهل النار

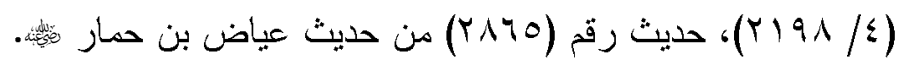
(YT)

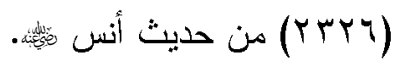

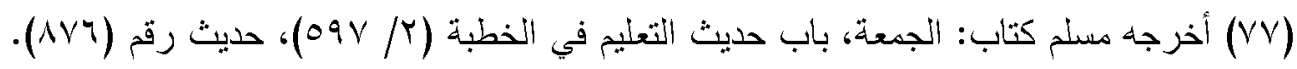

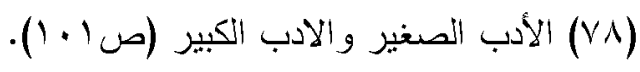

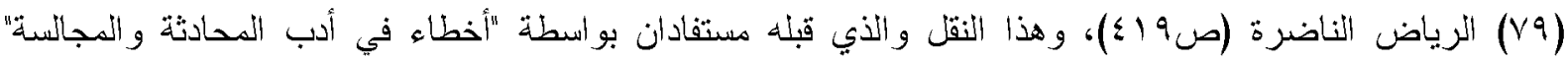

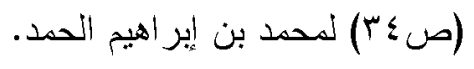




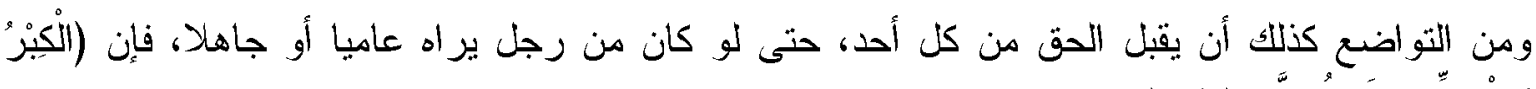

\section{الخاتمة :}

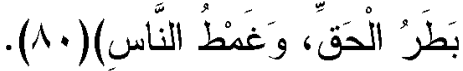

الحمد لله رب العالمين، وصلى الله وسلم على نبينا محمد و آله وصحبه أجمعين، أما بعد، فهذه أهم النتائج

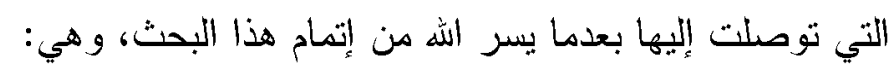

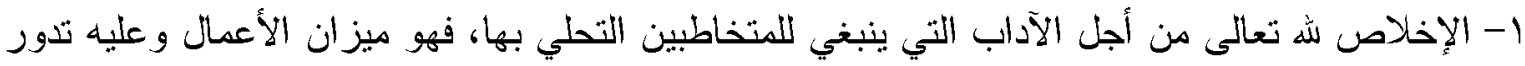
رحى القبول.

ب- لا يستقيم الخطاب بغير علم وفهم وتتبت، فالعلم ركن الخطاب الأعظم الذبي يكون به مؤثرا قويا مقنعا.

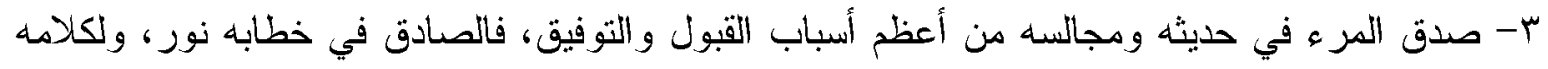

ع- البيان في المخاطبة والفصاحة من أعظم ما يؤثر في نفوس الناس، ولذلك ينبغي الحرصن على تعلم

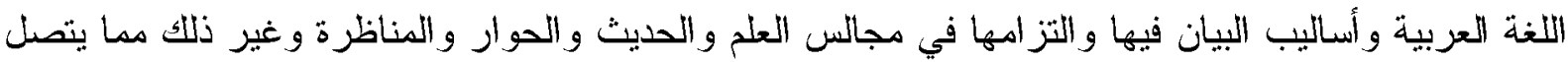
بحياة الناس. ه- القلوب النافرة، و النفوس الثائرة ما تُؤلِّت بمثل عذب المنطق وحلو الكلام، وما من شيءٍ أصدَّ للناس عن المتكلم من شدته و قسوته. ب- الجدال والمراء والخصومة من آفات الحوار والتخاطب بين الناس، ومتى سرت هذه الأدواء إلى ألى الخطاب كان ما يفسده أكثر مما يصلحه.

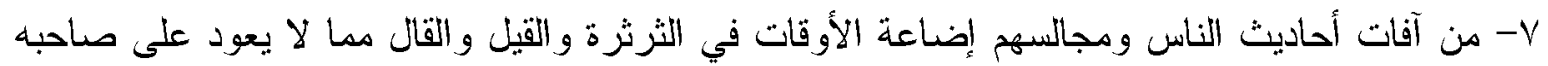
بعائدة ولا نافعة في الدنيا ولا في الآخرة.

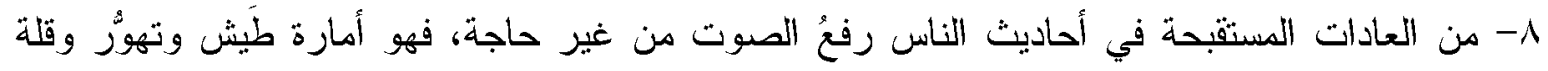
أدب. 9- الإقبال على المتحدث، ورعاية حديثه بالإنصات وحسن الاستماع من أهم آدب التخاطب، وليس من

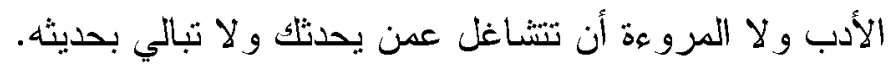

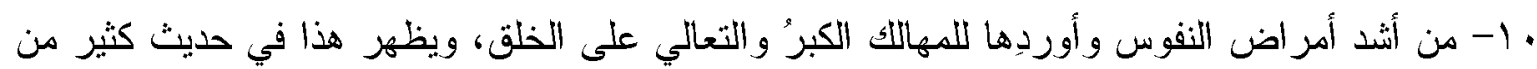
الناس ومحاور اتهم مع غير هم. التوصيات:

يوصي الباحث بضرورة إحياء أدب السنة النبوية الثريفة في التخاطب في بين أفراد المجتمع من خلال المحاضر ات و الدروات وخطب الجمعة و الفيديو هات القصيرة ووسائل التو اصل الاجتماعي.

(^) أخرجه مسلم كتاب: الإيمان، باب: تحريم الكبر وبيانه (1/9)، حديث رقم (9) من حديث عبد الله بن مسعود 


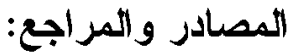

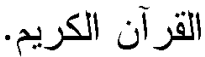

إحياء علوم الدين: أبو حامد محدد بن محمد الغزالي الطوسي (ته.0هـ)، دار المنهاج- جدة، طب-

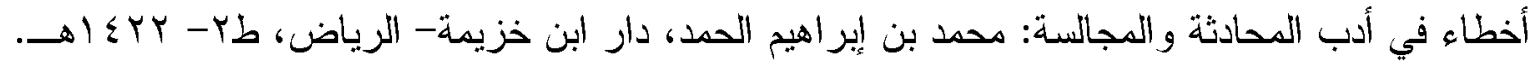

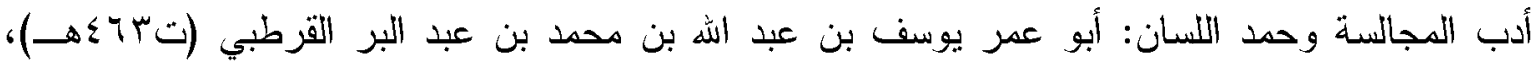

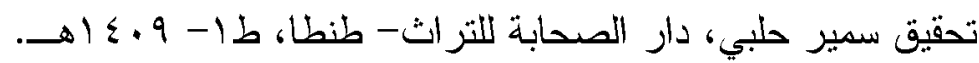

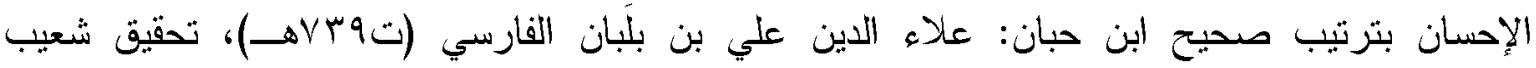

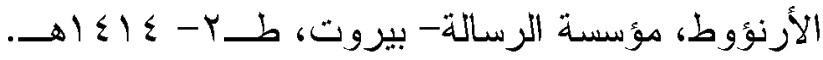

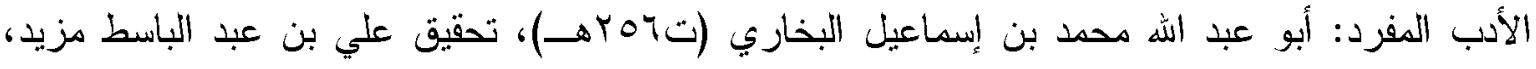

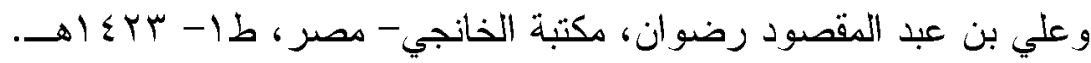

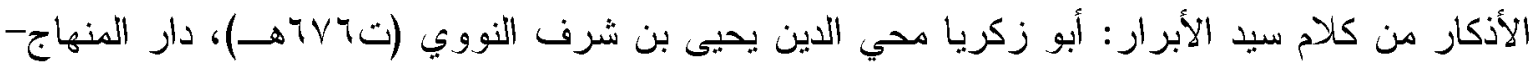

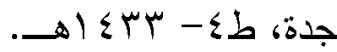
البيان والتبين: أبو عثمان عمرو بن بحر (الجاحظ) (تمهـهـ)، تحقيق عبد السلام هارون، مكتبة

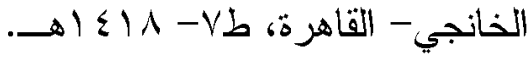

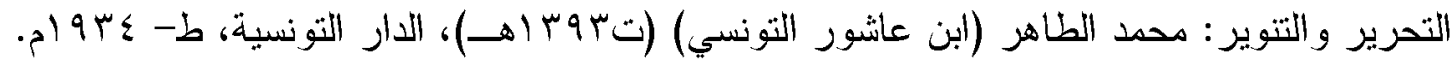

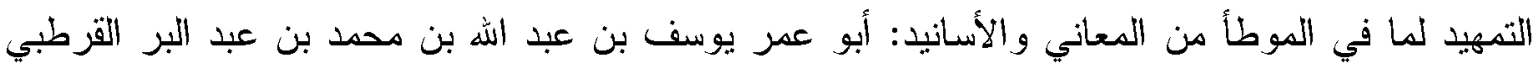

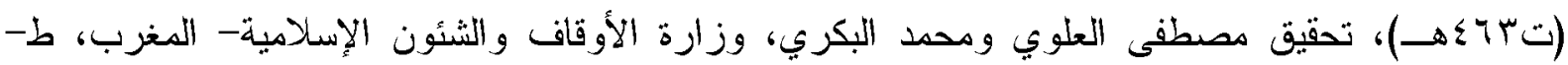
. $\rightarrow$ TNV

التوضيح لثرح الجامع الصحيح: سراج الدين أبو حفص عمر بن علي الأنصاري (ابن الملقِّ)

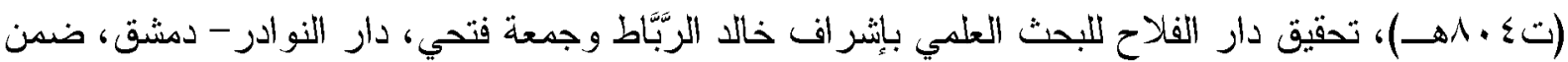

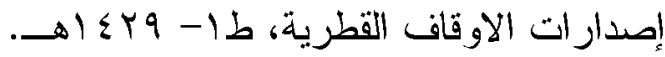

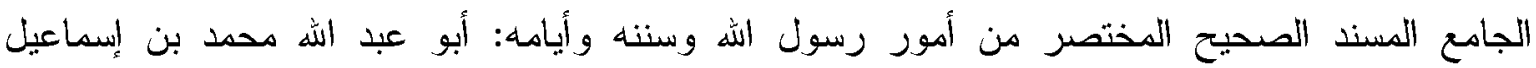

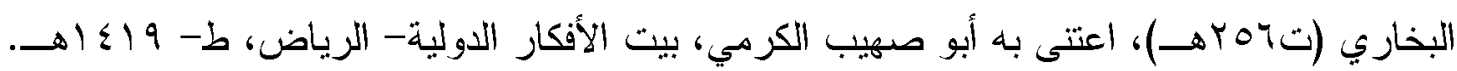

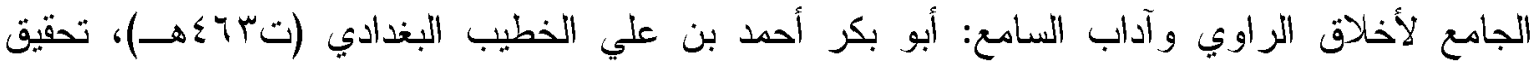

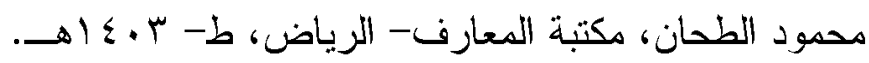

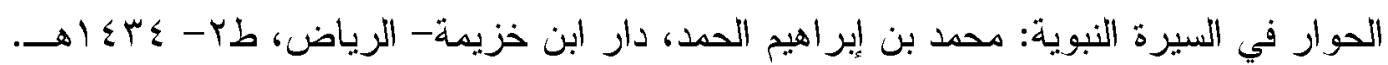
الداء والدواء: أبو عبد الله محمد بن أبي بكر (ابن قيم الجوزية) (تالهاهــ)، تحقيق محمد أجمل

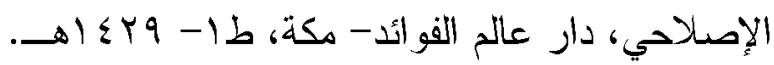

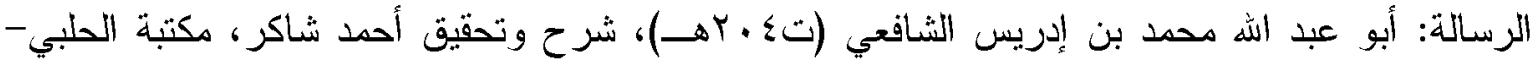

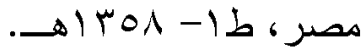
السنن الكبرى: أبو عبد الرحمن أحمد بن شعيب النسائي (تب.بهــ)، حققه حسن عبد المنعم شلبي،

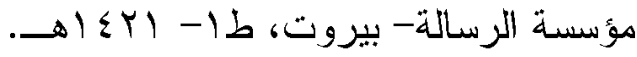




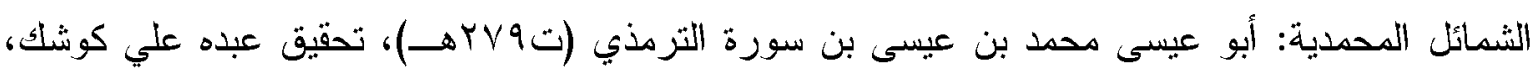

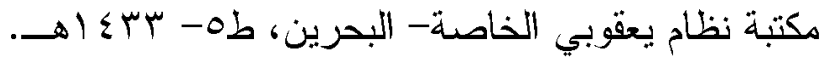

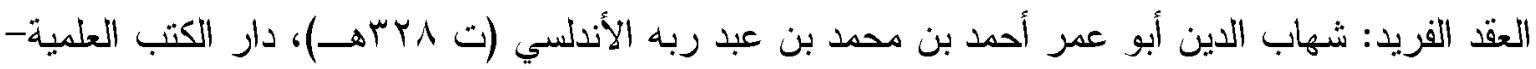

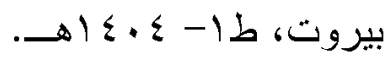
العلل الواردة في الأحاديث النبوية. المؤلف: أبو الحسن علي بن عمر بن أحمد بن مهدي بن مسعود بن

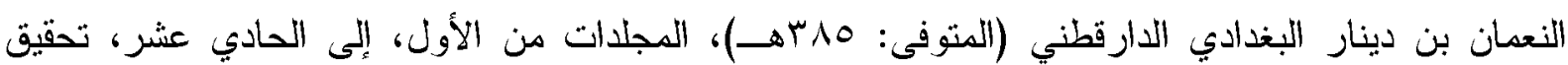

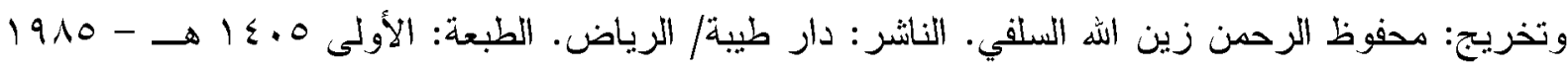
م. و المجلدات من الثاني عشر، إلى الخامس عشر، علق عليه: محمد بن صالح بن محمد الاباسي، الناشر : دار

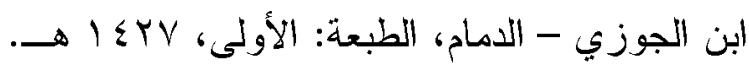
الفقيه و المتفقه، المؤلف: أبو بكر أحمد بن علي بن ثابت بن أحمد بن مهدب الخطيب البغدادي (المتوفى:

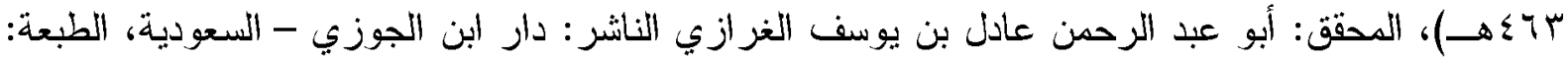

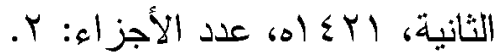
الكوكب الوهَّاج و الروض البهَّاج في شرح صحيح مسلم بن الحجاج: محدد الأمين الهررب الشافعي، دار

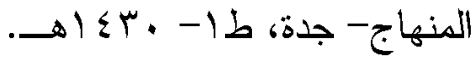

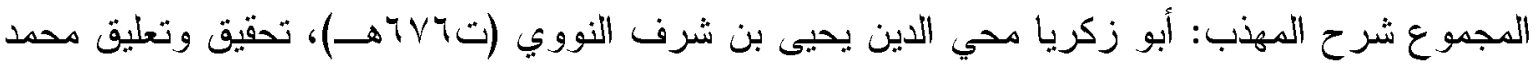
نجيب المطيعي، مكتبة الإرشاد- جدة.

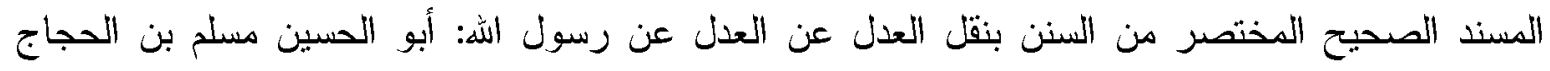

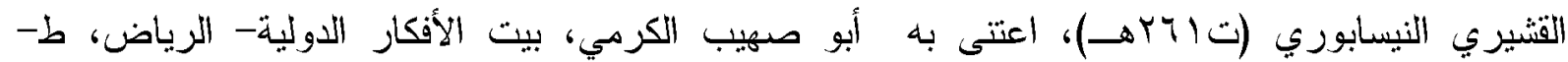

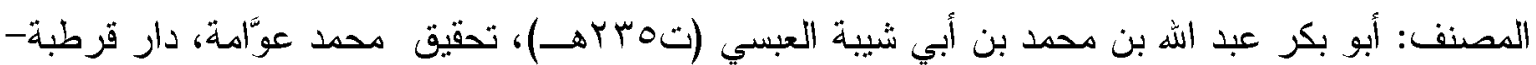

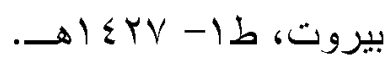

المطالب العالية بزوائد المسانيد الثمانية، المؤلف: أبو الفضل أحمد بن علي بن محمد بن أحمد بن حجر

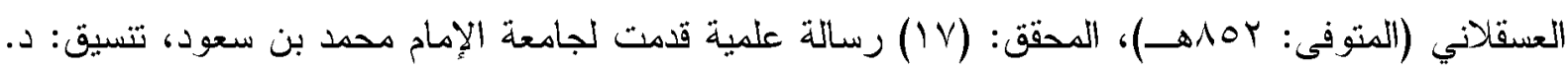

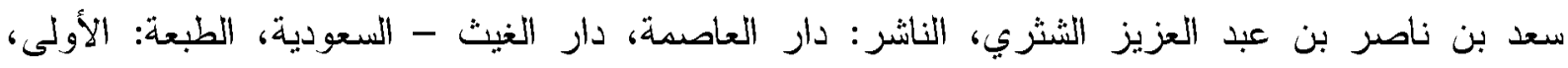

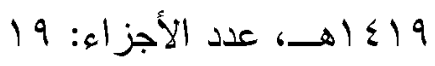

المعجم الكبير : أبو القاسم سليمان بن أحمد الطبراني (ت • بــهـ)، تحقيق حمدي عبد المجيد السلفي، مكتبة

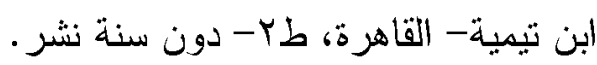

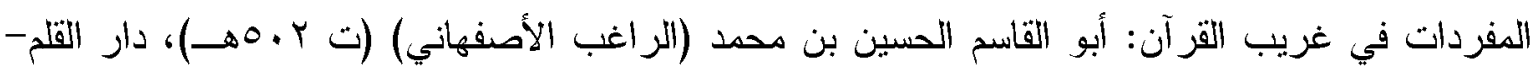

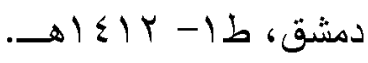

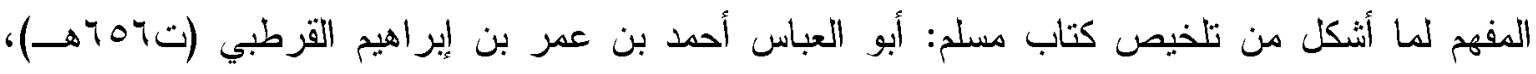

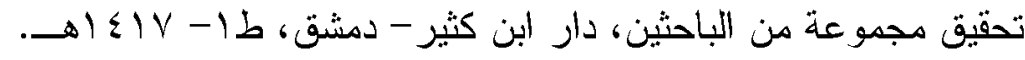
النهاية في غريب الحديث والأثر: مجد الدين أبو السعادات المبارك بن محمد الجزري (ابن الأبن الثير)

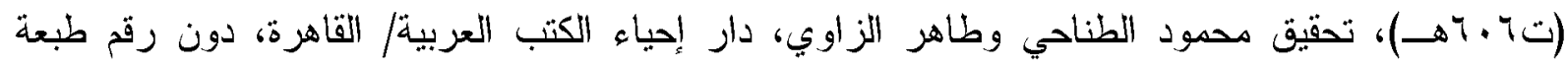


وسنة نشر · تصاح

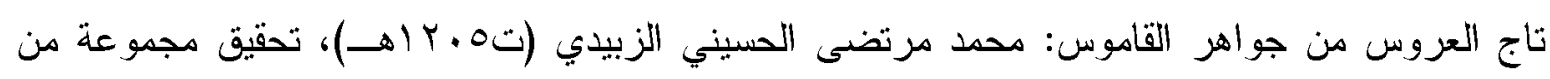

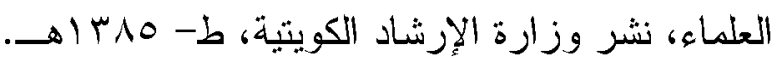

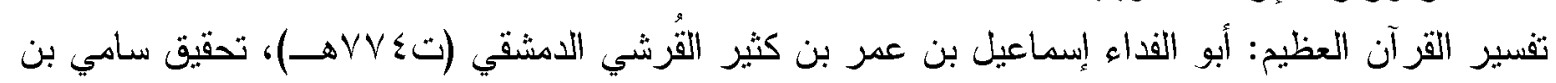

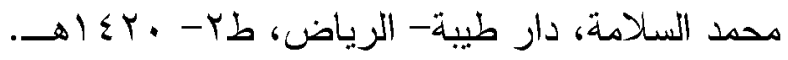

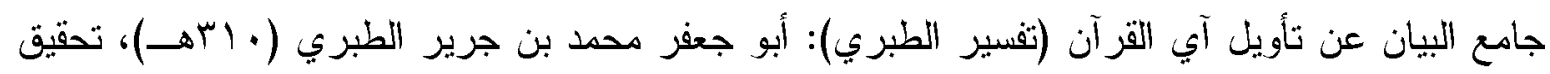

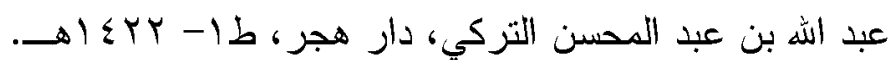

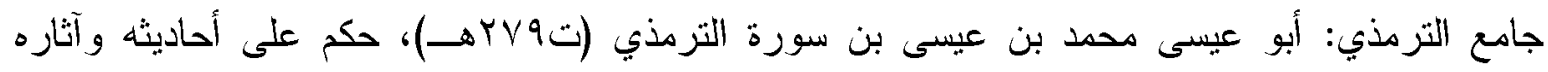

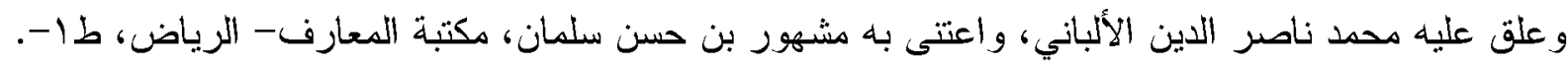
جامع العلوم والحكم: زين الدين أبو الفرج عبد الرحمن بن شهاب الدين البغدادي (ابن رجب البن الحنبلي)

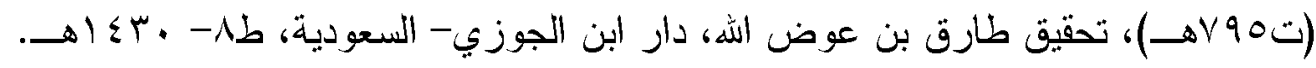

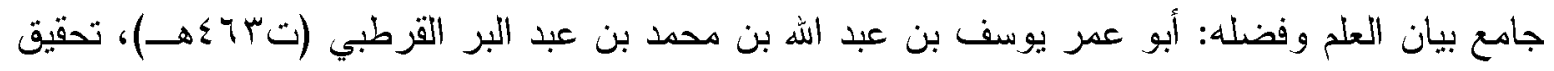

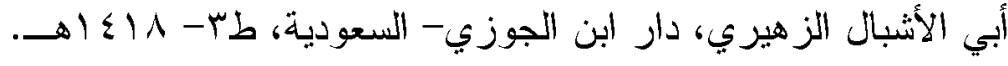

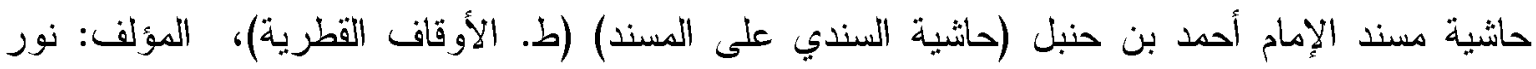

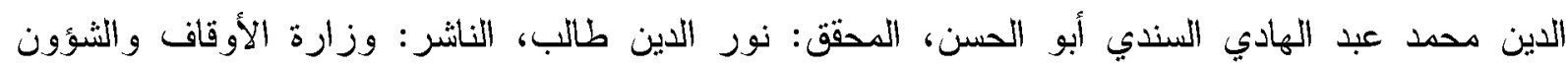

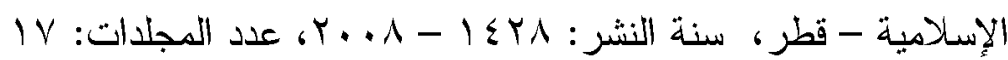

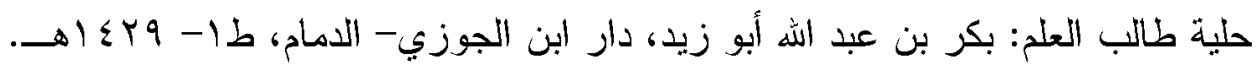

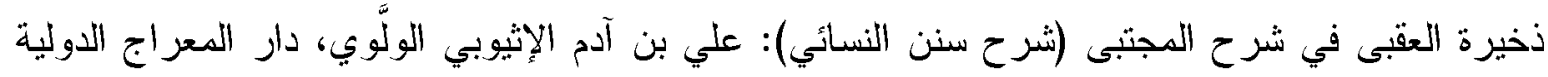

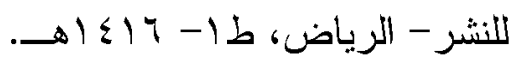

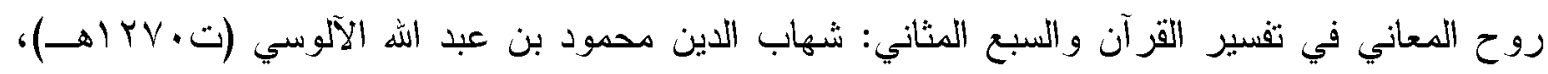

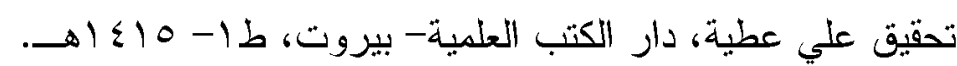
روضة العقلاء ونزهة الفضلاء: أبو حاتم محمد بن حبان البستي (تىهبهـهـان، تحقيق محمد محي الدين

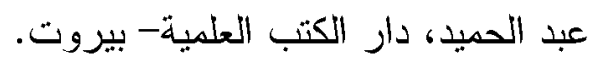

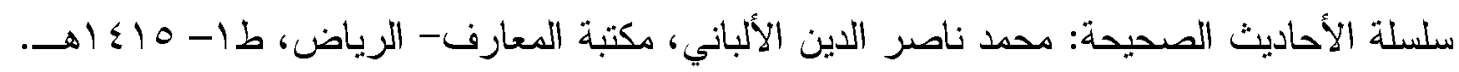

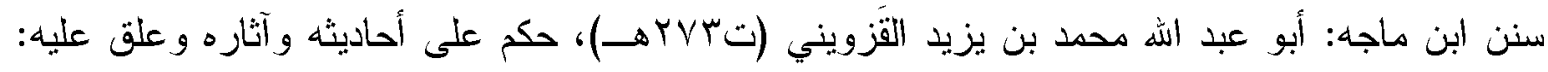

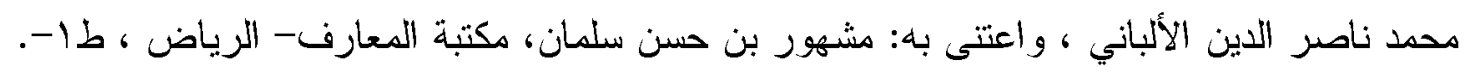

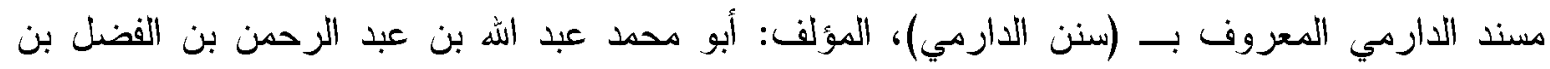

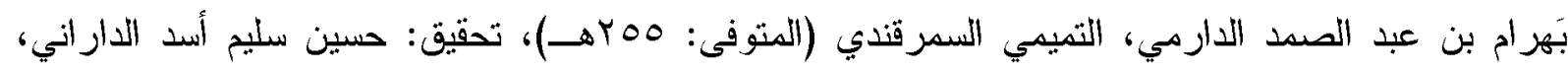

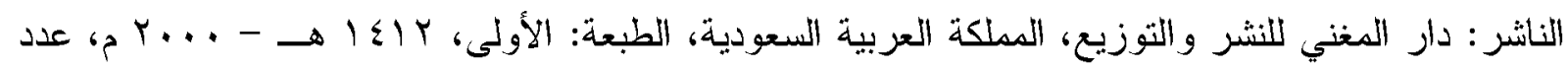
الأجز اء: ؛ ؟.

سبرة ابن إسحاق: محمد بن إسحاق (ت إهاهـ)، تحقيق سهيل زكار، دار الفكر- بيزوت، طا1 شرح النووب على مسلم: أبو زكريا محي الاين يحيى بن شرف النووي (ت7V7هـ)، دار إحياء التراث 


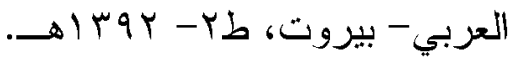

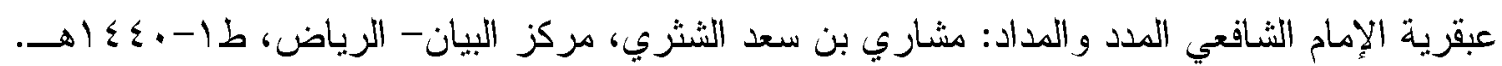
فتح الباري شرح صحيح البخاري: شهاب الدين أبو الفضل أحمد بن علي بن حجر العسقلاني

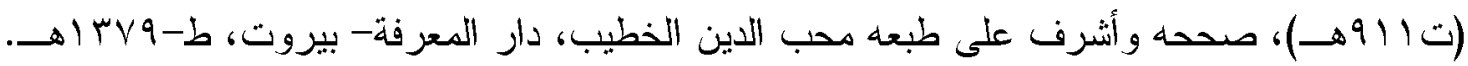

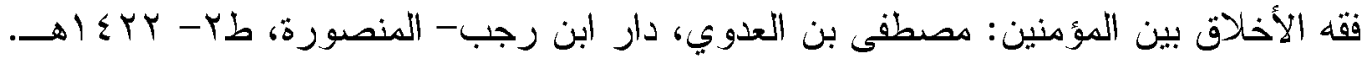

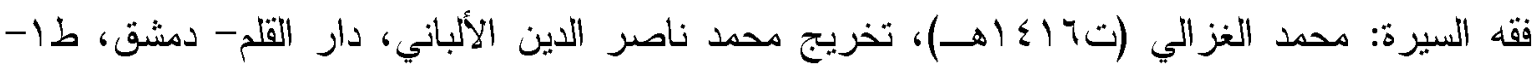
. $) \leqslant Y V$

كتاب الضعفاء: أبو جعفر محمد بن عمرو العقيلي المكي (ت بr بهــ)، تحقيق عبد المعطي أمين قلعجي،

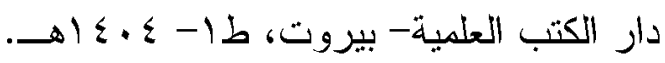

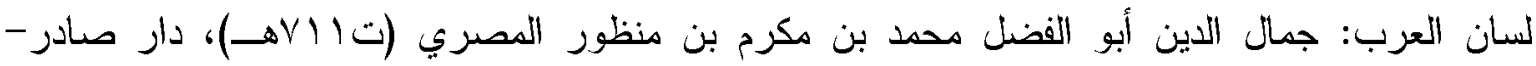
بيزوت، طس- ع إ اهـ.

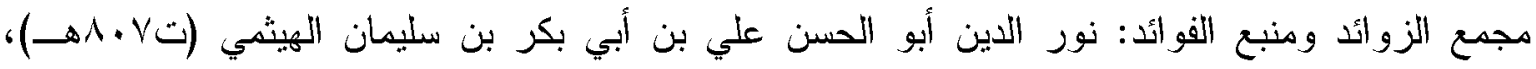

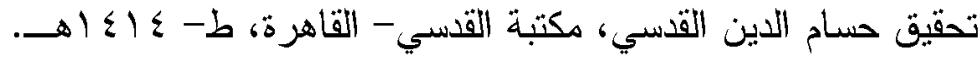

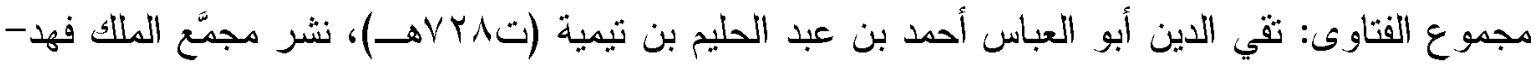

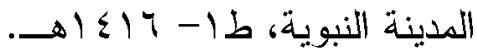

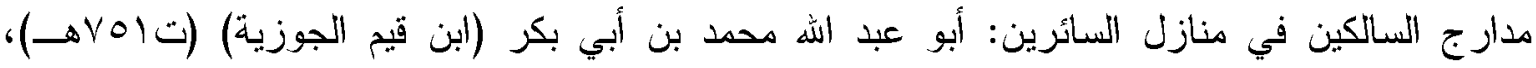

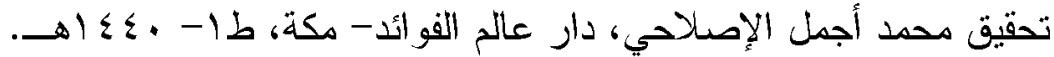

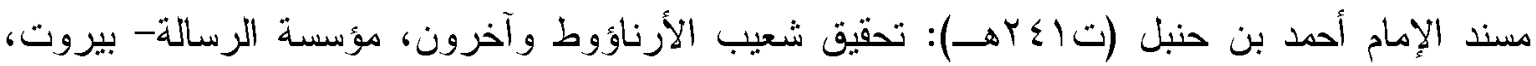
. $\rightarrow\{r \cdot-r$ معجم البلدان: شهاب الدين أبو عبد الله ياقوت بن عبد الله الحموي (ت بابآهـ)، تحقيق فريد عبد العزيز

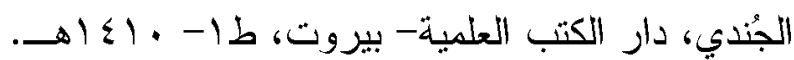

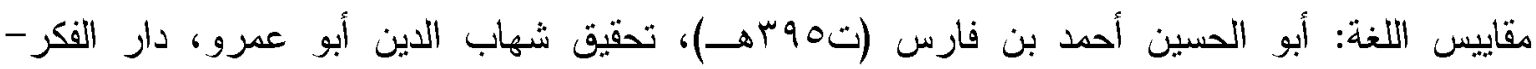

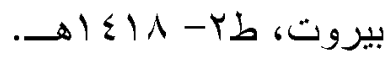
مناقب الثافعي: أبو بكر احد بن الحسين البيهقي (تNهـهـ)، تحقيق السيد أحد صقر، مكتبة دار

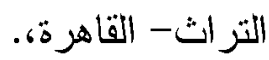

منهاج السنة النبوية في نقض كلام الثبعة القدرية: تقي الدين أبو العباس أحمد بن عبد الحليم بن تيمية

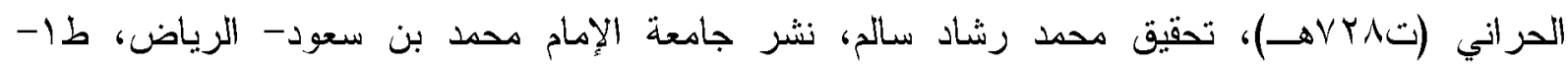
. 1 . 4 وأظلمت المدينة: نزار بن عبد القادر الريان، دار المنهاج- جدة، طب- عبـ اهـ. 